\title{
Batı Dijital Medyasının Türkiye'ye Yönelik Algı Manipülasyonu: Koronavirüs Haberleri Üzerine Ampirik Bir Araştırma
}

\author{
Mehmet Ulaş (Arş. Gör.)
}

iD İnönü Üniversitesi İletişim Fakültesi

mehmet.ulas@inonu.edu.tr

Abuzer Yeşil (Öğr. Gör.)

iD Malatya Turgut Özal Üniversitesi Kale Turizm ve Otel İşletmeciliği Meslek Yüksekokulu abuzer.yesil@ozal.edu.tr

Başvuru Tarihi: 06.04.2020

Yayına Kabul Tarihi: 30.05.2020

Yayınlanma Tarihi: 24.07.2020

https://doi.org/10.17680/erciyesiletisim.715586

\section{Öz}

İçinde bulunduğumuz dijital çağ dijital medya aracılığıyla aktarılan mesajların doğru bir okuma süzgecinden geçirilmesini önemli hale getirmiştir. Medyada kamuoyuna sunulan içeriklerin salt gerçekliği aktarmaması ve yeniden arzu edilen şekilde içeriklerin inşa edilmesi algı ve algı yönetimi kavramlarını gündeme getirmektedir. Medya gücünü elinde bulunduran mecralar kamuoyunun zihinsel dünyasında arzu edilen yönde fikirlerin yer almasını sağlamak amacıyla bazı stratejilerden yararlanmaktadırlar. Bu stratejilerin başında manipülasyon ve dezenformasyon teknikleri gelmektedir. Bu çalışmada nitel araştırma yöntemleri bağlamında amaçlı örneklem çeşitlerinden ölçüt örnekleme kullanılmıştır. Ölçüt örneklem için belirlenen üç kıstas bulunmaktadır: birincisi Corona virüs haberinde kullanılan görselin Türkiye'ye ait olması, ikincisi bu görselin kullanıldığ haberin içeriğinde Türkiye'nin yer almaması, üçüncüsü ise haberin dijital ortamda servis edilmiş olması şeklindedir. Belirlenen bu ölçütler bağlamında örneklem olarak BBC News, New York Times, CNN International, RT, The Associated Press, The Independent ve The Guardian medya organlarının Corona virüs ile ilgili dijital ortamlardaki haber içerikleri incelenmiş ve Türkiye'nin imajını olumsuz şekilde etkileyebilecek olan bu içerikler eleştirel söylem analizi bağlamında ele alınmıştır. Böylece bu çalışmada dijital medya ortamlarında manipülasyon ve dezenformasyon teknikleri ile birlikte yapılan algı yönetimi çabasının ortaya konulması amaçlanmıştır.

Anahtar Kelimeler: Dijital Medya, Algı, Algı Yönetimi, Manipülasyon, Dezenformasyon, Covid-19. 


\title{
The Manipulation of Perception Against Turkey by Western Digital Media: An Empirical Research on Coronavirus News
}

\author{
Mehmet Ulaş (Res. Asst.)
}

iD İnönü University Faculty of Communication mehmet.ulas@inonu.edu.tr

Abuzer Yeșil (Lect.)

iD Malatya Turgut Özal University Kale Tourism and Hotel Management Vocational School abuzer.yesil@ozal.edu.tr

Date Received: 06.04.2020

Date Accepted: 30.05 .2020

Date Published: 24.07.2020

https://doi.org/10.17680/erciyesiletisim.715586

\begin{abstract}
Reading correctly the transferred messages has become important through digital media in the digital age. The fact that the content presented to the public in the media hasn't conveyed the absolute reality and that the content have been reconstructed in the desired way have revived the concepts of perception and perception management. The mediums that have the power of the media have used some strategies in order to ensure ideas desired in the mental world of the public. Manipulation and disinformation techniques have been at the top of these strategies. In this study, criterion sampling, which is a purposeful sample in the context of qualitative research methods was used. There are three criteria for criterion sampling: firstly the image used in Corona virus news belongs to Turkey, secondly Turkey is not included in the content of the news using this image, thirdly news is served digitally. News contents in digital media related to Corona virus of BBC News, New York Times, CNN International, RT, The Associated Press, The Independent and The Guardian Media organs as samples were examined in the context of these criteria determined and these content that might affect Turkey's image in a negative way was discussed in the context of critical discourse analysis. Thus, it was aimed to reveal the perception management effort made with manipulation and disinformation techniques in digital media in this study.
\end{abstract}

Keywords: Digital Media, Perception, Perception Management, Manipulation, Disinformation, Covid-19. 


\section{Giriş}

İki temel medya yaklaşımından biri olan ABD merkezli liberal yaklaşım medyanın 'etki'si konusuna yoğunlaşırken bunu ampirik çalıșmalar neticesinde somut verilerle ortaya koymaya çalışmaktadır. Bu çalışmalar medyanın "güçlü veya sınırlı" etkileri olduğu sonuçlarına ulaşmıştır. Medyayı yasama, yürütme ve yargıdan sonraki 4. kuvvet olarak gören liberal yaklaşım, medyanın çok sesliliği sağladığı, insanlara farklı seçenekler sunarak bir düşünce pazarı oluşturduğu, siyasal iktidarı denetlediği, gözetimci rolü üstlendiği, dolayısıyla demokratik bir karakteri olduğu düşüncesini yansıtmaktadır. Avrupa merkezli eleştirel yaklaşımın medya ele alışı iletişim, toplum ve iktidar ilişkileri bağlamında gerçekleşmektedir. Medyanın "ideolojik" fonksiyonları ön plana çıkarılmaktadır. Kitle iletişim araçları ideolojik aygıtlardır. Hall; kitle iletişim araçlarının anlam ve anlam şekillerini yaratarak toplumda ideolojik bir fonksiyon icra ettiğini, dolayısıyla da kitle iletişim araștırmalarında önce medyanın ideolojisinin anlaşılması gerektiğini söylemektedir (Hall, 2014, s. 77-97). Eleștirel yaklaşımda kitle iletişim süreçleri toplumsal ve ekonomik yapı, dil ve kişilerin ruhsal durumlarıyla ilişkili olarak irdelenmiştir. Bu iletişim anlayışı dilbilim, felsefe, ruhbilim gibi farklı disiplinlere ait kuramların buluştuğu kavşak noktalarında şekillenmiştir (Altun, 2007). Bir eleştirel yaklaşım olarak değerlendirilen ekonomi-politik düşünce de sermaye ve üretimi kontrol edenlerin kitle iletişim araçlarını da kontrol ederek kendi lehlerine etki üretecek şekilde kullandıklarını ortaya koymaktadır.

Haber medya içeriğinde en temel işlevlerin başında gelmektedir. Medya bu işlevi haber olarak seçilecek toplumsal olgular, ele alma şekli, kullanılan dil ve aktarımda başvurulan tekniklerin etkin şekilde kullanılmasına kadar bir takım merhalelerden müteşekkil bir süreçte yerine getirmektedir (Kocabaşoğlu, 1977, s. 335-349). Liberal yaklaşıma göre medya profesyonelleri toplumsal gerçeklikleri anlama ve nesnel olarak aktarmayı başaran özerk ve mantıklı bireyler olup bu haberleri objektif olarak sunma kapasitesine de sahiptirler. Medyanın gerçekliğin aynası olduğu fikrinin bu noktada oluştuğu ifade edilebilir. Haberin nesnel sunumu için taraflara eşit mesafede olunması, bunun için de haberlerin dengeli verilmesi gerekmektedir. Denge için haberde kişisel düşünce, inanç ve duygu içeren yorumlarda bulunulmaması önemlidir. Denge için diğer bir durum ise haberin taraflarına eşit yer ve süre tanınması hepsinin düşüncelerinin aktarılmasıdır.

Eleştirel yaklaşım yönüne bakıldığında ise alt yaklaşımlarından biri olan araçsalcı yaklaşım, haberin yanlı olarak egemen sınıfların çıkarları doğrultusunda kurulduğunu ve dolayısıyla nesnel haberin söz konusu olamayacağını kabul etmektedir (Murdock, 1980, s. 39-57). Bu yaklaşıma göre haberci, medya patronunun kişisel çıkarları ve ait olduğu sermayedarlar sınıfının çıkarlarını devam ettirecek ölçüde mevcut gerçekliği çarpıtmaktadır (Dursun, 2003, s. 63-83). Bu durum medyanın manipülasyon ve algı oluşturma yönüne dikkat çekmektedir. Eleştirel yaklaşıma göre haber yapılanmış bir sürecin mamulüdür ve bu üretim süreci da haberin nesnel ve objektif olabileceği yanılsaması üzerine bina edilmiştir. Haber üretim sürecinde haber değeriyle ilişkili şekilde üretilen haber, aktarılan olay dışında ve ona karşın kurulabilir. Bu yönden bakıldığında haber, gerçeği temsil eden bir metin şeklinde kurulmaktadır. Bundan dolayı, "habercilik te inşa edici/kurucu bir pratiktir, bir iştir" (Dursun, 2003, s. 63-83).

Medyanın dijitalleștiği çağımızda manipülasyon ve algı yönetimi konuları bu bağlamlarda yoğun bir şekilde tartışılmaya devam etmektedir. Bu tartışma etrafında birçok çalışma yapılmıştır. Rek-Wozniak ve Wozniak (2020) yapmış oldukları çalışmada BBC'nin Ukrayna ve Polonya'da düzenlenecek olan Euro 2012 organizasyonuna 11 gün kala 
yayınlamış oldukları 'nefret stadyumları" belgeseli ile algı yönetimi çabasında olduklarını ve ahlaki bir panik algısı oluşturmak istediklerini ortaya koymaktadır. Liang ve Wang (2020) ise yapmış oldukları çalıșmada haber ajanslarının ve medya profesyonellerinin dijital medya ortamında manipülatif etki oluşturmadaki rolünü ele almışlardır. Morgan (2018) ise yapmış olduğu çalışmasında ile dijital medyanın gelişen teknoloji sonrasında siyasette manipülatif amaç ile kullanıldığından bahsetmektedir. Kellner (2004) yapmış olduğu çalışmada 11 Eylül saldırılarından sonra Bush'un medyayı etkin bir şekilde kullanarak tüm dünya üzerinde olumlu bir imaj inşası içerisinde olduğunu belirterek medyanın siyasette aktif kullanımı ve algı inşası gücünü ortaya koymuştur. Aydınalp (2019) yapmış olduğu çalışmada terör örgütü PKK'nın, TSK tarafından Ağustos 2015 ile Haziran 2016 tarihleri arasında gerçekleștirdiği 'Hendek Operasyonları' sırasında sosyal medya üzerinden yürütülen devlete yönelik kara propaganda ve terör örgütüne yönelik propaganda amaçlı manipülatif Twitter paylaşımları incelenmiştir. Toktay (2019) yapmış olduğu çalışmada ürk Silahlı Kuvvetleri ve Özgür Suriye Ordusu'nun müşterek düzenlediği Zeytin Dalı Harekatı'na yönelik terör örgütü PKK/YPG ve sempatizanlarının sosyal medyadaki dezenformasyon, manipülasyon ve propaganda uygulamaları, nitel araştırma yöntemlerinden içerik analizi ve daha çağdaş bir araştırma yöntemi olan netnografi kullanılarak ortaya çıkarılmakta ve örgütün sosyal medya algı yönetimi stratejisi ve teknikleri örnekler eşliğinde açıklamaktadır.

Dijital medyada içeriklerin çok hızlı bir şekilde güncellenebilmesi, haber akışının çok hızlı hale gelmesi manipülasyon ve algı yönetimlerini daha kolay yapılır hale getirmektedir. Zira izleyici ve okuyucular tarafından birçok haberin içeriğine ilişkin sorgulama yapma zamanı dahi kalmayabilmektedir. Bu çalışmada son dönemlerin en önemli tartışma konularının başında gelen Coronavirüs (Covid-19) hakkında dijital Batı medyasında yapılan haberlerin içeriklerinde Türkiye'ye dönük manipülatif ve algı inşa edici yaklaşımların ortaya çıkarılması hedeflenmiştir. Özellikle Türkiye ile ilgili içeriği olmayan haberlerde Türkiye görsellerinin kullanılmasının arka planı belirlenmeye çalışılmıştır. $\mathrm{Bu}$ bağlamda ölçüt örnekleme ile belirlenmiş olan BBC News, New York Times, CNN International, RT, The Associated Press, The Independent ve The Guardian gibi medya organlarında yer alan bulgular değerlendirilmiştir.

\section{Dijital Medya Üzerinden Dezenformasyon ve Manipülasyon İnşası}

Dijital medya kavramı geleneksel medya yapısının dijitale evirilmiş șeklini izah etmek için kullanılmaktadır. Dijital medyanın sosyal medyayı da içeren geniş bir kavramsallaştırma olduğu gerçekliği karşımıza çıkmaktadır. Dijital medya diğer ismi ile yeni medya yalnızca paylaşım merkezli uygulamaları değil aynı zamanda bütün dijitalleşme gösteren medya araçlarının da ifade ediliş biçimidir (Demirel, 2018, s. 825).

Dijital medya sunmuş olduğu enformasyon ile kitleler halinde yaşayan toplumsal yapıyı etkilemekte aynı zamanda bu etkiyi oluştururken medyanın gücünü elinde bulunduran güç odaklarının düşünce yapısını temsil etmesi bağlamında da başka bir baskıya maruz kalmaktadır. Dijital medya isteyerek veyahut istemeden kurgulanan sanal gerçekliklerin paylaşımına imkân sunmaktadır. İsteyerek veya istem dışı bir şekilde paylaşılan iletiler, gerçek dışı bilgiler, sosyal medya aplikasyonları üzerinden erişim sağlayan kullanıcıların zihinsel dünyasında manipülatif etkiler inşa edebilmektedir.

Tarihi gelecek, siyasal yapı ve finansal durum bağlamında güç merkezi haline gelmek için uğraş gösteren mecralar açısından kitle iletişim araçlarının kontrolü ve yönlendirici gücünü elinde bulundurabilir olmak kritik bir avantajdır. Kitle iletişim araçlarının 
üzerinde inşa edilen denetimi elinde bulundurmanın sağladığı yadsınamaz imkânlar ve yararlar vardır. Kitle iletişim araçları gündem belirleme etkisinden ötürü toplumsal yapının hangi mesele hakkında konuşacağını, dikkatini hangi sorunlara veyahut çözümlere yönlendireceğini belirlerken aynı zamanda bu mecraları elinden bulunduran güç sahiplerinin faaliyetlerini meșru ve değerli gösterirken karşı tarafı olumsuz sunup o yöne olabilecek eğilimleri engellemek istemektedir.

Dijital medyada karşımıza en çok çıkan kavramların başında manipülasyon (bir grubun yada şahsın kendi istekleri doğrultusunda gerekirse zarar vererek talep ettiği şeyleri karşı tarafa kabul ettirebilme sanatı) (Pratt, 2017, s. 2-8) ve dezenformasyon (Webster sözlügünde “dezenformasyon kelimesinin dezenformatzia'dan tercüme edildiği, kamuoyunda etki oluşturmak veyahut gerçeklikleri saklamak için, kasıtlı bir şekilde doğru olmayan bilgilerin gizlice yayılması) kavramlarının geldiği yadsınamaz bir gerçekliktir. (Çınarlı, 2004, s. 169-170).

Chomsky'e göre; kitle iletişim araçları bir manipülasyon, denetim inşası aracı ve beyin yıkamaya yönelik olarak kullanılan güçlü ve ayrıcalıklara sahip kimselerin kendi menfaatlerine hizmet etmekte olan araçlardır. Medyanın bu sanal gerçeklik pratikleri bağlamında Batı dünyasında ifade edilen ve üzerinde sıklıkla durulan basın özgürlüğü meselesi özelinde duyulan kaygıların inandırıcılığı bulunmamaktadır. Oysa ki demokratik bir iletişim politikasının kamuoyunun faydasını gözeten bunun yanı sıra kaygılarını ifade etme şansı tanıyan yapıda olması gerekmektedir. Bunun dışında tasarlanan ve kamuoyuna sunulan politika medyanın gücünü elinde bulunduran mecraların kendi kişisel çıkarları ve menfaatleri doğrultusunda ortaya koymuş oldukları bir politikadan başka bir şey olmayacaktır (Chomsky, 2002, s. 205).

Amerika'da "zihin menajerleri" şeklinde tanımlanan bireyler bir mesele hakkında istenilen imajların oluşturulmasında ve bu oluşturulan imajın hedef kitleye aktarılmasında kritik bir rol üstlenirken aynı zamanda bu amaç doğrultusunda sosyal gerçeklik pratiği ile bağdaşmayan mesajlar oluşturabilmekte, bu mesajlar ile kasıtlı bir şekilde yaratılan manipülasyon sayesinde sunulan içeriklerin gerçeklikten ayrı olarak istenilen biçimde algılanmasına sebep olmaktadır. Paulo Freire, bireyin zihin dünyasının manipülasyonunu bir tür fetih vasıtasına benzetmektedir. Toplumun iktidarını elinde tutan seçkin şeklinde izah edilen kişiler kendi çıkar ve menfaatleri bağlamında kitleleri yönlendirebilme gücünü elinde bulundurmaktadır. Kamuoyunun bilinci şekillendirirken iki temel teknikten faydalanılmaktadır. Bunlardan ilkini iletişim formu oluşturmaktadır. Mitler, bireylere hükmedebilmek adına kullanılmakta ve kamuoyunun bilinç dünyasına profesyonelce yerleştirildiği takdirde bireyler düşünce dünyalarının manipüle edildiğinin farkına dahi varamamaktadır. Bölünmüşlük şeklinde izah edilen bu teknik, enformasyon iletiminde ve haber akışı meselesinde sıklıkla kullanımına başvurulan bir tarzdır. Hedef kitleye sunulan enformasyonda görülen bölünmüşlük, tüketim ekonomisinin bizlere öğrettiği görülen her boşluğu reklam ile doldurma ihtiyacının bir yansımasıdır. Her türlü haberde, enformasyon iletimi sırasında aralara reklamların sokulması, hedef kitlenin bütünü anlamlandırabilme pratiğini zorlaştırmakta ve istenilen şekilde manipülasyon inşa edilemesine olanak sunmaktadır. İkinci tekniği ise enformasyonun güncelliği oluşturmaktadır. Güncellik meselesi bölünmüşlük durumuna hız kazandırtmanın yanı sıra, enformasyon iletim sisteminin manipülasyon etkisini arttırmaktadır. Medyanın gücünü elinde bulunduran seçkinler birden fazla teknik ve yöntem ile hedef kitlenin zihinsel dünyasının manipülasyonunu inşa edebilmektedir. Bu durum medyanın hedef kitle üzerindeki etkisinin izahını oluşturmaktadır (Mora, 2011, s. 168-171). 
Dijital medyada ise manipülasyon birçok tekniğin kullanımı ile gerçekleştirilebilir. Sözgelimi; sunulacak olan iletilerin içerisinde yer alan görseller üzerinde montajlama sayesinde farklılıklar ortaya konulabilir. İletinin içeriğini oluşturan metinler değişime uğratılarak veyahut eksik bir şekilde sunularak gerçekliğin dişından bir bağlam üzerinde inşa edilebilir ve doğru olanın çok ötesinde farklı anlamlar ve hedef kitle tarafından algılamalar ortaya çıkabilir. Gerçeklikte varlığı söz konusu olmayan veriler kamuoyunu tarafından sözüne inanılacak kişiler kaynak gösterilerek sunulabilir. Sahte hesaplar kurularak gerçeği yansıtmayan enformasyon iletileri kişilere sunulabilir. Bireyler üzerinde korkuya sebep olacak içerikler tehdit ve güvensizlik hissi ile birlikte sosyal medya platformlarında yayılabilir. İletinin içeriğinde kullanılan sesler, görseller ve renk yanılsamalarıyla bireylerin zihin dünyalarına istenilen özellikleri bünyesinde barındıran mesajlar verilebilir. Farklı farklı ileti içeriklerin ayrı ayrı veyahut birlikte ve aynı zamanda sistematik olarak kullanımı ile çeşitli kahramanlar oluşturulabilir. Bu unsurlar bir araya getirildiği zaman sosyal linç, gerçek dışı hesaplar, sahte bir şekilde kurgulanan etiketler vasıtası dijital medya ortamında manipülasyon ve algı yönetimini noktasında kullanılan tekniklerdir (Eraslan, 2018, s. 129-219).

Dezenformasyon; devletler, istihbarat birimleri ve medyada hedef kitle üzerinde arzu edilmekte olan davranışları oluşturabilmek amacıyla yürütülmekte; bu amaçlara uygun faaliyetleri kitle iletişim araçlarını kullanarak, provokatörler aracılığıyla ve son dönemin toplumsal yapı içerisinde popüler iletişim ortamı olarak adlandırılan yeni medya vasıtası ile gerçekleştirmektedir. Dezenformasyon, enformasyon toplumunda bir problemdir ve bu durum toplumlara zarar verir (Yoloğlu, 2017, s. 8-15).

Dezenformasyon genel anlamda gerçeklik ile ilişkisi bulunmayan bir olay veya olguyu varmış gibi aktarmak hedefi ile üretilmiş olan yalan/yanlış bilgi tabanıdır. Bu üretilen bilgiler bilinçli bir şekilde yanlışlar üzerine üretilmekte ve hedef kitlenin zihinsel dünyasına ve harekete geçecek eylemlerine yönelik beklentilerin istenileni yakalama çabası gütmektedir. Dijital medya ortamları bu dezenformasyon yayımı bakımından gücü elinde bulunduranlara çok önemli fırsatlar sağlamaktadır Dezenformasyon bir organizasyon veyahut da bir birey eliyle üretiliyor olsa da dönem dönem haber kanalları tarafından ve bazen de gazeteler tarafından kasıtlı bir şekilde üretilmiş olan enformasyonu referans alarak gerçeği yansıtmayan haberler kurgulayabilmektedir. Medyanın burada ki asli görevi dezenformasyon üretmek veya üretilenin kaynağl olmamakla birlikte, dezenformasyon amacına yönelik üretilmiş olan bilgilere taşıyıp hedef kitleye yönelik iletiyi ulaştırmaktır (Turan C. , 2015, s. 110). Dijital medyanın alt dallarından olan sosyal medya vasıtası neticesinde küresel bağlamda artışın görüldüğü gerçeği yansıtmayan ve hedef kitleyi yanıltabilecek haberlerin çoğu ülkede kritik etkileri görülmüş ve sosyal, ekonomi ve politik olaylarda tabir yerinde ise tahribat gücü ve olasılığı yüksek olan kitlesel etki oluşturacak bir silaha evirilmiștir. Dijital dünya karakteristik özellikleri bağlamında salt bir şekilde fikirlere etki etmeye odaklanmaz bunun yanı sıra gerçek olmayan, bir kısmı gerçeklik taşıyan iletileri sunarak dedikodu oluşturup kafa karışıklığı ile güvensizliği tırmandırıp nesnel bir realitenin varlığının olduğu fikrine adeta meydan okur (Manor, 2018).

Manipülasyon ve dezenformasyon arasındaki ilişkisellik şu şekilde ifade edilebilir: Dezenformasyon, manipülasyonu yapabilmek adına kullanılan bir yöntemi temsil eder. Kullanılan bu yöntem geleneksel medyadan ve dijitalleşen medyadan güç edinen bir sistemdir. Salt bir şekilde geleneksel medya araçları ile değil gelişen teknolojik yapı ve değişen toplumsal yapı ile birlikte hayatımıza dahil olan dijital medya da olanakları ile 
dezenformasyon ve manipülasyona imkan sağlayan ortamlardır. Haberlerin içeriğini oluşturan iletilerin yanı sıra içerikte kullanılan görsel unsurların da serbest bir şekilde ve kontrol mekanizması olmaksızın dolaşımına imkân sağlayan dijital medya ortamları, hedef kitle konumunda yer alan kamuoyunun farklı ve istenilen şekillerde yönlendirmelerine maruz kalmasına sebep olabilmektedir. Dijital dünyanın kritik unsurlarından olan internet bünyesindeki teknik donanım özellikleri sayesinde görüntü üzerinden inşa edilen manipülasyonuna olanak tanımakta, bunun yanı sıra haberlere konu teşkil edebilecek bir görsel içeriğin doğruluk yönünün birden fazla kaynak tarafından denetlenmesini gerekli kllar vaziyettedir (Bozkurt, 2012, s. 111).

Küreselleşen dünyada medyanın toplumsal yapı üzerinde bir güç unsuru olduğu gerçeğini fark eden sermaye sahibi kişilerin, yapmış oldukları yatırımları enformasyon alanına doğru gerçekleștirdikleri görülmektedir. Yaşanan bu gelişmeler haberlerin karakteristik özelliklerinde değişim yaşanmasına sebep olmuş ve adeta haber gerçeği yansitan toplumsal bir ahlak meselesinden belli bir cenaha hizmet eden ticari bir metaya dönüşmüştür. Bu durum haberlerin sunduğu içerik bağlamında bir dezenformasyona uğramasını ve hedef kitleye yönelik bir manipülasyon inşasını hedeflediği gerçeğini karşımıza çıkarmaktadır. Medya toplumun dünya üzerinde yaşanan gelişmelere yönelik olarak doğru, tarafsız ve gerçeği yansıtan bilgi elde etme ihtiyacını karşılamak gibi önemli bir misyonunu arka plana atarak, sunulan haberlerde güç odaklarının faydasını ve çıkarlarını gözeterek manipülatif etkiye sahip içerikler inşa etmeye başlamış ve reyting ve tirajları yükseltmeyi amaç edinen yeni ve gerçekliği tartışılır bir hale gelen habercilik anlayışını kendine misyon edinmiş durumdadır. Bu yaşanan dönüşümlerden ötürü toplumsal yapı içerisinde yer alan bireylerin anlam dünyasının düzenli bir halde oluşmasında söz sahibi pozisyonda bulunan medya kuruluşlarından bireylere aktarılan mesajların, gerçeklik olgusunu ne kadar temsil ettiği son dönemlerde sıklıkla tartışılmaktadır. Çeşitli programlar yardımı ile haber içeriğinde sunulan görsellerde ve videolarda inşa edilen manipülasyonlar ve bilinçli bir şekilde üretimi yapılan içerikler bireylerin fikir dünyasını, değerlerini ve gerçeklik anlayışını değiştirilebilir bir konuma gelmiştir. Özellikle siyasi amaçlar doğrultusunda kritik öneme sahip kamuoyunun arzu edilen şekilde düşünmesini sağlamak bakımından bu imkânlar bir firsat bütünü sağlamaktadır. Bireylerin yönlendirilmesinde önemli bir etkiye sahip olan haber içerikleri ile düşünce dünyasına yönelik çeşitli algıların inşa dilmesi ve zihinsel bir bulanıklığın ortaya çıkarılması sağlanmaktadır.

\section{Dijital Medya'da Algı ve Gerçeklik ile Toplum Mühendisliği}

Algl, bireyin çevresinde yaşanan olaylara ve etrafındaki durumlara yönelik farkında olma durumu şeklinde izah edilebilir. Algıların zihinsel dünyada yoruma tabi tutulması, devamında değerlendirilmesi ve anlamlandırılmasına, neticesinde ise bilinçli bir biçimde zihinsel bütünlük ortaya koymasına algılama denilmektedir. Algılamanın oluşabilmesi açısından uyarıcının, bireyi herhangi bir tepkiye yönelten en alt düzeyi temsil eden mutlak algı eşiğinin üzerinde yer alması gerekir (Turan H. , 2015, s. 186). Algı bir dizi işlemin, bir sürecin neticesini temsil etmekte ve herhangi bir meseleye yönelik algının oluşması için bir uyarıcının yanı sıra uyarım, bir duyum ve duyumu alabilecek bir organizmanı varlığı şeklinde izah edilebilecek ana unsurlar gerekmektedir. Bu ana unsurlar arasındaki ilişkisellik ve organizmanın uyarıcıdan edindiği duyumları kayıtlı halde bulunan bilgiler aracılığıyla örüntülemesi neticesinde da algı oluşmaktadır. Bu örüntüleme sürecinin ifadesi ise organizasyon șeklinde isimlendirilir. Algının birden fazla türü mevcuttur. 
Simgesel, görsel, duygusal ve seçimleyici algı şeklinde algı türleri bunlardan birkaçını yansitmaktadır (Karabulut, 2014, s. 316-318).

Algı Yönetimi kavramı ise, ABD Savunma Bakanlı̆̆ı tarafından literatüre kazandırılmıștır. $\mathrm{Bu}$ açıdan algı yönetimi kavramsallaştırması, dış tarafta bulunan izleyicilerin duygu dünyalarına, güdülerine ve son olarak amaçlarına etkide bulunmak hedefiyle seçilmiş olan enformasyonu yayma faaliyetidir. Görüntü itibari ile hedeflenenler ve elde edilen sonuçlar bakımından propaganda ile benzeşik özellikler taşısa da, araçsal ve yöntemsel açıdan farklılıklar bulundurmaktadır. Bu farklılıklardan önemli olanı, tek yönlü ve de dikey bir süreçten öte, çok yönlü ve yatay bir süreç şeklinde olmasıdır (Erol \& Ozan, 2014, s. 186-187). Dijital medyanın bir ürünü olan sosyal medyada ise algı yönetimi kavramsallaştırması şu şekilde izah edilmektedir: Sosyal medyanın bünyesinde barındırdığı birden fazla araç ve aplikasyonları kullanıp (ses, resim, video, mesaj vd.) bir gruba ya da kişiye yönelik kurgulanan sistematik yönlendirme şeklidir. Sosyal medya aracılığıyla uygulamaya konulan alığı yönetimi tekniklerini çeşitli başlıklar altında toplamıştır. 18 başlık altından toplanan yöntemler şu şekildedir: 1-İçerikte yer alan görsellerin manipüle edilmesi, 2- içerikleri Cımbızlama ve Çarpıtma, 3- içerikte yer alan videolarda montaj ve kurgu, 4- İçeriğe konu olan kişinin Magazinleştirmesi ve itibarsızlaştırması, 5-içerikteki enformasyonları uydurma ve neticesindeki enformasyon manipülasyonu, 6-İçerikte yer alan istatistik verileri ile yanıltma, 7-İçerikte yer alan meselenin meşrulaştırılması, 8-Sanal köstebeklik yapma, 9-İçerikte yer alan iletiler ile infial yaratma, 10-Zihinsel dünyada etki üretme, 11-İçerik ile bir kahraman veyahut sosyal mit yaratma, 12-Sosyal ağlar üzerinden kampanya inşa etme, 13-Yapılan yorumlar ve beğeniler üzerinden bir algı yönetimi, 14- Etiketleme yapmak, 15-Dijital ortamda olan Sosyal linç, 16-Gerçeği yansıtmayan Sahte(Fake)hesaplar, 17- çağrışım ve 18- Yasa dışı göstermedir (Eraslan, 2018, s. 119-219).

Gerçeklik kavramsallaştırması gerçek kavramından hareketle kullanılmakta olan, gerçek anlamda varlığı olan şeylerin tümünü izah etmekte kullanılır. Gerçeklik, ayrı bir hedef gözetilerek tasarımdan geçirilen, düşünülen, imgelenen şeylerin tersine gerçekte karşılığı olan ve bu karşılığı algıdan bağımsız bir şekilde var olan olguların tamamıdır (Akarsu, 1984, s. 83). İçinde bulunduğumuz dönemin izahında kullanılan iletişim ve kitle iletişim araçlarının, teknolojik bağlamdaki gelişmelere ve insan hayatını kolaylaştırmaya dönük söylemleri ile içinde bulunduğumuz gerçeklik pratiği arasında çelişkilerin olduğu yadsınamaz bir gerçekliktir (Babacan, Haşlak, \& Hira, 2011, s. 71).

Jean Baudrillard simülakrlar simülasyon eserinde günümüzde medyanın her türlü alana uzandığından gerçekliğe yönelik algının köklü bir değişime uğradığını ifade etmiştir. Bunun neticesi olarak yaşamakta olduğumuz fiziki gerçeklik ile medya eliyle oluşturulan sanal gerçeklik ve kendi ifadesi ile hipergerçeklik şeklinde iki tür gerçeklik olgusunun oluştuğunu belirtmektedir. Baudrillard'a göre gerçeklik algısı ile ilgili bir sakatlanma yaşayan toplum bu sakatlığın neticesinde sağlıklı bir şekilde düşünme yetisini kaybeder ve son olarak bir tepkisiz kalma ve sessiz yığınlara dönüşme gerçekleşir (Baudrillard, 2018, s. 111).

Medya, üretilen içeriklerin tarafsız ve objektif yapısını kaybetmesinden ötürü gerçeklik olgusu bağlamında her zaman bir tartışmaya konu olmuştur. Bireyler medya aracılığıyla kendilerine sunulan gerçeklik ile kendi yaşantıları arasındaki gerçeklik arasında bir karşılaştırma yapmaktadırlar. Medyanın bireylere sunmuş olduğu gerçeklikler sadece hayatın gerçekliğinden kesitlerdir. Medyada yaşanan teknolojik gelişmeler bir taraftan 
hayatı kolaylaştırmakta lakin diğer taraftan gerçek olan ile yanılsama olan arasındaki farkın idrak edilmesi noktasında zorluk oluşturmaktadır. Medya enformasyon depolayan ve bunu hedef kitleye ileten araçlar konumuna gelmiştir. Algı yönetimi ile birlikte düşünüldüğünde medyanın tanımlanma şekli değişime uğramış ve medya bilginin üretildiği, bu bilgilerin kitlelere aktarımı sağlayan bunu yaparken belirlenen hedefler doğrultusunda gerçekliği çarpıtan ve hedefe uygun bir şekilde ileti hazırlayan araçlar olarak ifade edilebilir. Günümüz medyasının misyonu hedef kitleyi oluşturan toplumsal yapıya yönelik doğru ve tarafsız bir bilgi aktarımı değil çıkar ve menfaatlere göre şekillenen içeriklerin sunulduğu ve bir ekonomik politiğin temsili olan yapıya dönmüştür. $\mathrm{Bu}$ bağlamda medya toplumsal yapıyı arzu edilen yönde dönüştüren bir toplum mühendisliği görevi üstlenmiştir. Karabulut, 'toplum mühendisliği' kavramsallaştırmasını şu şekilde ifade etmektedir: Toplumu oluşturan gruplar ve sınıfların belirlenen hedefe yönelik şekilde biçimlendirilmesini amaç edinen düzenlemeler bütünüdür (Karabulut, 2014, s. 97). Kişilerin, grupların veyahut da toplumların bilinçli bir şekilde manipüle edilmesi meselesinde karşımıza çıkan kavramsallaştırma toplum mühendisliğidir. Toplum mühendisliği, hedeflenen planlar neticesinde toplumun mevcut yapısı içinde sahip olduğu inançlar, değerler bütünü, kültürel yapı ve ahlaki anlayışlarında; kişilerin arzularının dışında yer alan değişikliklerin inşa edildiği, sistematik planlar bütününün izahıdır. Bu tip faaliyetlerin karakteristik özellikleri bir değișim ve dönüşüme kapalı olan toplumsal yapılarda ya da toplumun bu yaşanacak olan değișeme hazır bulunmadığı dönemlerde gizli bir şekilde, imajlar oluşturarak, manipülatif anlatımlar yoluyla ve aktörler tarafından yürütülmesidir. Nasyonal sosyalistler ise toplum mühendisliği kavramlaştırmasını toplumun bütününü yanıltmak şeklinde kullanmışlardır (Özdağ, 2015, s. 198).

Algı yöneticileri belirledikleri hedef kitlelerinin istenilen hale gelmeleri sürecinde çeşitli yollar tercih etmektedirler. Yöneticiler ilk olarak hedef kitle hakkında detaylı bilgileri elde etmekte ve onların süreçteki zayıf yönlerini tespit etme gayreti göstermektedirler. Sonra bu veriler ışında konunun özelinde temalar ve sloganlar ortaya koymaktadırlar. Tam da bu dönemde işin içine dâhil edilen medya ile birlikte bir sanal gerçeklik inşası yapılmakta ve hedef kitlenin sanal ile gerçeklik arasında ki ayrımı yapabilme durumu zorlaştırılmaktadır. İzahı gerçekleştirilen bu meseleyi Amerikalı Siyasetçi Henry Kissinger şu şekilde yorumlamaktadır "Bir durumun gerçeklik teşkil etmesi çok önemli bir detay değildir lakin gerçekmiş gibi algılanması son derece önemli bir detaydır" şeklinde dile getirilmiştir (Öksüz, 2013, s. 12-15). Modernleşme kuramcılarına göre medyanın modernleşme ve kalkınma sürecinde kritik bir rolü vardır, medya modernleşmenin ve kalkınmanın destekleyici gücü konumundadır çünkü medya modernleşmenin araçsal halidir. Medyanın dördüncü süper güç konumunda olması burada medyaya yüklenen anlamın ne kadar önemli olduğunun göstergesi niteliğindedir. Medyanın asli görevi hedef kitleye doğru ve tarafsız bir bilgi akışını gerçekleştirmesidir. Ancak modernleşmenin aracı şeklinde izah edilen medya, toplum mühendisliği tasarımının hayat bulması, istenilen şekilde dizayn edilen mesajların hedef kitleye sunulması bağlamında ve yarattığı algı ile adeta toplumu yönetmenin bir "aracına dönüşmüş durumdadır.

Enformasyon ve iletişim alanında yaşanan gelişmeler, toplumsal yapıya yönelik yönlendirmeleri bir baskı ile değil de gizli olarak yürütülmekte olan stratejik çalışmalar ile gerçekleştirebilmeyi mümkün kıldığı gibi zorunlu da kılmaktadır. Teknolojinin sağladığı bu firsatlar sayesinde hedef kitleye yönelik olarak istenilen bilgiler elde edilebilmektedir. $\mathrm{Bu}$ bilgiler toplum mühendisliğinin inşasını üstlenenler tarafından hedeflerine yönelik kaynak teşkil etmektedir (Atabek, 2003, s. 12). 
Günümüzde yaşanan toplumsal ve teknolojik gelişmeler toplumsal yapıyı ekonomik anlamda, siyasal ve kültürel anlamda bütün iletilere açık bir çeşit enformasyon tüketimi toplumuna dönüștürmüștür. Üretilmiș olan yeni teknolojiler ile birlikte bireylerin sıkı bir şekilde denetime tabii tutulduğu, her türlü içeriğin ve iletinin değişime uğratılarak belirli hedeflere doğru yöneltildiği, dezenformasyon ve de manipülasyon aracılığıyla küresel ölçekte harekete geçirilen toplum mühendisliğinin etkileyici bir hız ve ivme ile bütün toplumlara uyarlandığı ve uygulandığı görülmektedir.

Medya, arzu ettiği bir gerçekliği inşa edip bunu istenilen şekilde iletiye dönderip hedef kitleye sunarak manipülasyon yapabilmektedir. Burada asıl amaç kitleleri yönlendirebilmek, etki altına alabilmek, arzu edilen biçimde düşünmeye sevk etmektir. Mumford'un ifadesiyle, "mekanik yeni dünya kurulmuştur (Mumford, 1996, s. 45).

Sonuç olarak algı yönetimi ile birlikte bir toplum tasarısında bulunmak isteyenler, her geçen gün gelişim gösteren ve kendini yenileyerek yoluna devam eden dijital medyaya ve dijitalleșen insana karşı duyarsız kalmamıştır. Dijital medya ve gelişen teknolojik yapının neticesi olan ve kullanım oranları göz önüne alındığında sosyal medya aplikasyonları bu duyarsız kalmayıșı haklı çıkarır neticededir. Geleneksel medya anlayışı ile birlikte inşa edilemeye çalışılan algı ve toplum mühendisliği dijital medya ve dijital medyanın sunmuş olduğu firsatlar ile çok daha hızlı ve uygulanabilir bir hale gelmiştir. Özellikle sosyal medyada etkili bir kontrol mekanizmasının varlığının olmayışı bu alanların daha da provokasyona açık bir hale gelmesini sağlayan unsurlardandır. Belirli bir amaç doğrultusunda hedef kitlenin detaylı bir analizi oluşturulmak istenen toplum mühendisliğinin temelini oluşturur. Doğru stratejik hamleler ile doğru içeriklerin hazırlanması ve bu içeriklerin doğru medya kanalları ile sunulması da yeni toplumsal yapının görselliğini ortaya koymaktadır.

\section{Yöntem}

Teun A. van Dijk, Eleştirel Söylem Analizi, alışılagelmiş söylem analizi kavramsallaştırmalarının yanı sıra ideoloji, toplumsal yapı, egemenlik, güç, yeniden üretim, toplumsal düzen, sınıfsal yapı ve cinsiyet kavramlarını içermektedir (Van Dijk, 2015, s. 465-485). Van Dijk'ın Eleştirel söylem analiz modeli Makro ve Mikro yapı şeklinde iki bölümde ele alınmıştır. Makro yapıda haberin girişi, habere konu olan ana olay, haberde geçen olayı izah eden kaynaklar ve haber içeriğindeki bağlam bilgisi gibi unsurlar yer almaktadır. Mikro yapıda ise haberden kullanılan cümlelerin etken/edilgen ya da basit/bileşik yapıda olduğunu inceleyen sentaktik çözümleme, haberin içeriğindeki cümlelerdeki neden sonuç ilişkiselliği ortaya koyan bölgesel uyum, haberler içeriğinde ideolojik olarak muhabir veya editörün yaklaşımını ortaya koyan sözcük seçimleri ve haberin inandırıcılığını ve ikna ediciliğini inceleyen retorik çözümlemeleri yer almaktadır. (Özer, 2012, s. 137-138).

Çalışmada BBC News, New York Times, CNN International, RT, The Associated Press ve The Independent ve The Guardian kanallarının Corona virüs ile ilgili dijital ortamlardaki paylaşımları amaçlı örneklem tekniği ile taranmış, bu paylaşımlarda Türkiye'nin imajını olumsuz şekilde etkileyebilecek olan haber içerikleri eleştirel söylem analizi bağlamında ele alınmıştır. Böylece bu çalışma ile bu kanalların başka ülkelerle ilgili olan Coronavirüs haber içeriklerinde Türkiye görsellerine yer vermesi ile oluşturulmak istenen olumsuz algı ve olumsuz bilinç inşa etme çabasının ortaya çıkarılması amaçlanmıştır. 


\section{Bulgular}

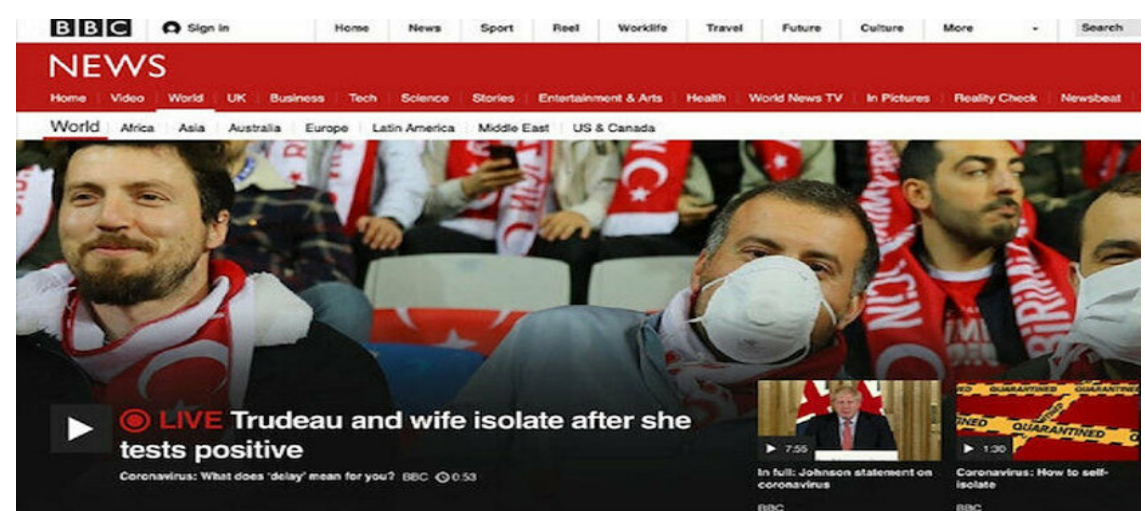

Şekil 1: BBC News Haberi

Kaynak: https://www.ahaber.com.tr/gundem/2020/03/18/son-dakikaindependentten-kirli-algi-operasyonu-baskan-erdogani-hedef-gosterdiler

Tablo 1: BBC NEWS Haberi Cözümlemesi

\begin{tabular}{|l|l|}
\hline Başık & $\begin{array}{l}\text { Trudeau and wife isolate after she tests positive (Trudeau ve eşi, eşinin } \\
\text { testini pozitif çıkmasından sonra kendilerini izole ettiler) }\end{array}$ \\
\hline Haberin Girişi & $\begin{array}{l}\text { Sophie Grégoire Trudeau, wife of Canadian PM Justin Trudeau, has tested } \\
\text { positive for coronavirus after returning from a trip to London, a statement from } \\
\text { the PM's office says (Başbakanlık ofisi yaptığı açıklamada, Kanada Başbakanı } \\
\text { Justin Trudeau'nun karısı Sophie Grégoire Trudeau'nun Londra'ya yaptığı } \\
\text { geziden döndükten sonra koronavirüs için yaptırdığı testin çıktığı belirtildi) }\end{array}$ \\
\hline Fotoğraf & Türkiye'de oynanan bir futbol karşılaşmasının tribünlerinden bir enstantane \\
\hline Durum & $\begin{array}{l}\text { Kanada Başbakanı'nın eşinin Covid-19 testinin pozitif çıkması üzerine Başbakan } \\
\text { Trudeau ile beraber sosyal izolasyona tabi olmaları habere konu olmuştur. } \\
\text { Başkakan'ın kendisi enfekte olmamasına rağmen onun da bir süre yalnız } \\
\text { kalacağını ifade eden haberde eşinin son durumu ile ilgili de bilgi verilmiştir. }\end{array}$ \\
\hline $\begin{array}{l}\text { Sentaktik } \\
\text { Çözümleme }\end{array}$ & $\begin{array}{l}\text { Haber Kanada Başbakanlık Ofisi'nin diliyle verilmiş ve genelde etken çatılı cümleler } \\
\text { kullanılmıştır. Hem basit hem de bileşik cümleler haberde yer almaktadır. }\end{array}$ \\
\hline Böıgesel Uyum & $\begin{array}{l}\text { Haber içeriğinde önce Kanada Başbakanı'nın eşinin sağlık durumundan bahsedip } \\
\text { sonra başbakanın izolasyona yönelmesinden ve ardından da başbakanın teste } \\
\text { gerek duymamakla birlikte işlerini yürüteceğinden söz etmektedir. Son olarak } \\
\text { ta Kanada'da resmi olarak tespit edilmiş vaka sayısı verilmektedir. }\end{array}$ \\
\hline $\begin{array}{l}\text { Sözcük } \\
\text { seçimleri }\end{array}$ & $\begin{array}{l}\text { Haber muhabir ya da editör kaynaklı olmadığı için birincil ya da ikincil kaynak söz konusu } \\
\text { değildir. Editör haberi düzenlerken nötr bir tavır takınmış, haberin içeriğine etki etmemiştir. }\end{array}$ \\
\hline Haber Retoriği & $\begin{array}{l}\text { Haber Kanada Başbakanlık Ofisi'ne dayandırılarak güvenilirliği sağlanmaya } \\
\text { çalışımıştır. Yine Kanada'daki resmi vaka sayısı verilerek bu durum pekiştirilmiştir. } \\
\text { Ancak haberde kullanılan görsel Türkiye'den olup haberin içeriğiyle ilgisi } \\
\text { bulunmamaktadır. Bu durum bir algı yönetimi çabası görüntüsü vermektedir. }\end{array}$ \\
\hline
\end{tabular}

Yukarıda çözümlemesi yapılmış olan haberde Türkiye ile ilgili bir içerik olmamasına rağmen haberin sunumundaki görselde Türkiye ile ilgili bir fotoğrafın kullanılması Covid19 virüsü ile ilgili Türkiye’ye dönük bir algı çalışması izlenimi uyandırmaktadır. Haber içeriği ile görsel birlikte değerlendirildiğinde 'Kanada Başbakanının eşinin Londra seyahati dönüşünde yapılan Covid19 testinin pozitif çıkmasına rağmen haberin görselinde Türkiye ile ilgili bir görselin kullanılmış olması bir İngiliz medya organı olan BBC News'in dikkatleri Londra'dan uzaklaştırıp Türkiye'ye yöneltmeye dönük bir algı yönetimi çalışması șeklinde okunabilir. 


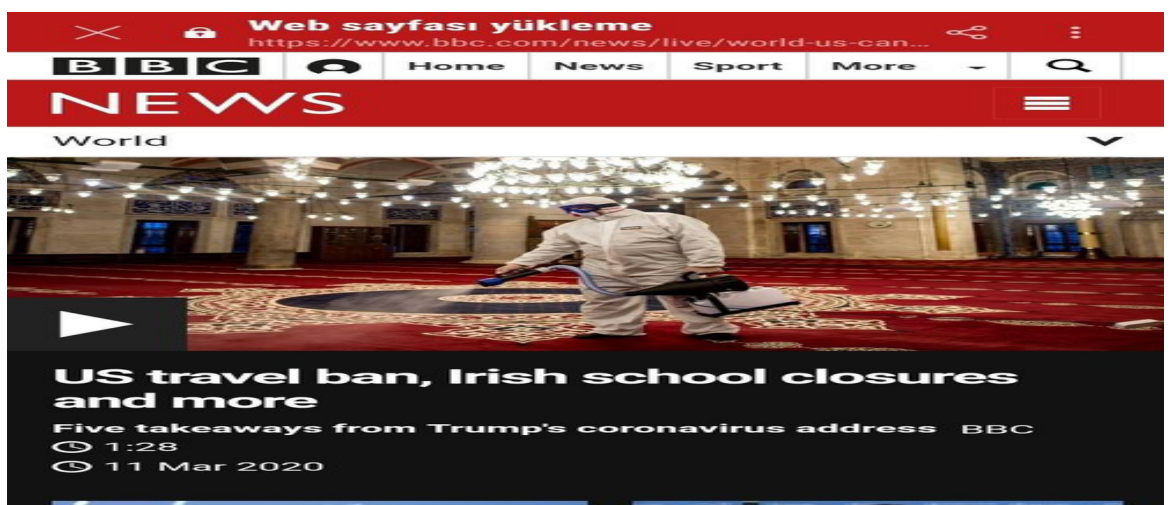

Şekil 2: BBC News Haberi

Kaynak: https://www.takvim.com.tr/guncel/2020/03/16/uluslararasi-medya-ve-turkiyedekiuzantilarindan-cirkin-algi-operasyonu-koronavirus-haberlerinde-ulkemizi-hedef-aldilar

Tablo 2: BBC NEWS Haberi Cözümlemesi

\begin{tabular}{|l|l|}
\hline Başık & $\begin{array}{l}\text { US travel ban, Irish school closures and more (ABD seyahat } \\
\text { yasağı, İrlanda okul kapanışları ve daha fazlası) }\end{array}$ \\
\hline Haberin Girişi & Five takeaways from Trumps coronavirus adress (Trump'tan koronavirüse dönük beş paket) \\
\hline Fotoğraf & İstanbul'daki Kılıç Ali Paşa Camii \\
\hline Durum & $\begin{array}{l}\text { ABD Başkanı Donald Trump'ın coronavirüs tedbirleri bağlamında açıkladığı beş } \\
\text { paket, yine coronavirüs sebebiyle İrlanda'da okulların kapanması ve batıdan } \\
\text { yine virüs ile ilgili bazı haberler haberin içeriğinde yer almaktadır. }\end{array}$ \\
\hline $\begin{array}{l}\text { Sentaktik } \\
\text { Çözümleme }\end{array}$ & $\begin{array}{l}\text { Haberde edilgen çatılı cümleler kullanılmasının yanı sıra hem basit } \\
\text { hem de bileşik cümleler haberde yer almaktadır. }\end{array}$ \\
\hline $\begin{array}{l}\text { Bölgesel } \\
\text { Uyum }\end{array}$ & $\begin{array}{l}\text { Haber içeriğinde öncelikli olarak ABD Başkanı Trump'ın virüs bağlamında almış oldukları } \\
\text { beş paketlik önlemlerin izah edildiği görülmektedir. Aynı zamanda batı dünyasının } \\
\text { virüs ile ilgili mücadelesine yer verilen haberde son olarak tedbirlerin artırılmasına } \\
\text { ve sıkı tedbirlerin her geçen gün artarak gidebileceği ihtimaline yer verilmiştir. }\end{array}$ \\
\hline $\begin{array}{l}\text { Sözcük } \\
\text { seçimleri }\end{array}$ & $\begin{array}{l}\text { Van Dijk'in eleştirel söylem analizinde birincil kaynak olan muhabir tarafından kaleme alınan } \\
\text { bir haber içeriğidir. Lakin muhabirin içeriğe yönelik bir etkisinin olmadığı görülmektedir }\end{array}$ \\
\hline $\begin{array}{l}\text { Haber } \\
\text { Retoriği }\end{array}$ & $\begin{array}{l}\text { Haberin içeriğinde ABD yönetiminin virüse yönelik almış olduğu beş paketlik } \\
\text { önlemin detaylarından bahsedilmesi ve Avrupa'nın örnek verilerek sayısal verilerin } \\
\text { ortaya konulması güvenilirlik anlamında önemlidir. Lakin haberde hiçbir ilgisi } \\
\text { olmamasına rağmen haberin görselinde Türkiye'den Kılıç Ali Paşa camisinde } \\
\text { temizlik yapııırın ki bir fotoğrafın sunulması haberde ki önemli kıstaslardan olan } \\
\text { doğruluk kıstasını ortadan kaldırmakta ve güvenilirliği düşürmektedir. }\end{array}$ \\
\hline
\end{tabular}

Yukarıda çözümlemesi yapılmış olan haberde ABD ve bazı Avrupa ülkelerinin virüse karşı tedbirleri işlenmiş olmasına rağmen İstanbul'daki Kılıç Ali Paşa Camii'nin ilaçlanması görseli servis edilmiştir. Haberin yapıldı̆̆ı tarihte henüz Türkiye'de Covid19 virüsüne rastlanmamıșken sanki Türkiye' de de salgının var olduğu algısı inşa edilmeye çalıșılmıștır. Aynı zamanda bu algı inşa edilmeye çalışılırken görselde özellikle caminin kullanılıyor olması bilimsel tedbirler yerine dinsel sembollerin daha fazla önemsendiği algısına sebebiyet vermektedir. 


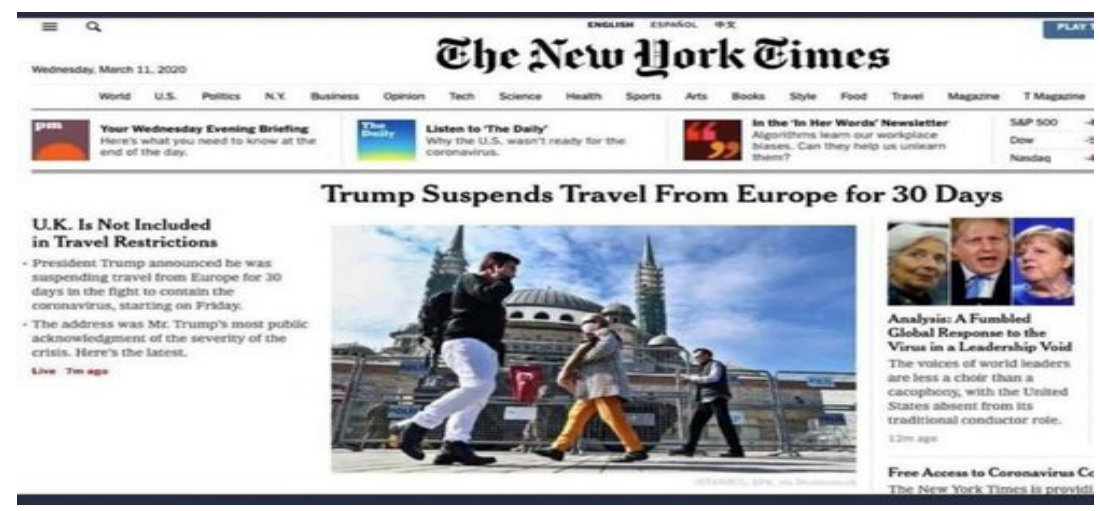

Şekil 3: The New York Times Haberi

Kaynak: https://www.ahaber.com.tr/gundem/2020/03/18/son-dakikaindependentten-kirli-algi-operasyonu-baskan-erdogani-hedef-gosterdiler

Tablo 3: The New York Times Haberi Çözümlemesi

\begin{tabular}{|c|c|}
\hline Başlık & $\begin{array}{l}\text { Trump Suspends Travel From Europe for } 30 \text { Days (Trump } \\
\text { Avrupa'dan Seyahat Etmeyi } 30 \text { Gün Askıya Aldı) }\end{array}$ \\
\hline Haberin Girişi & U.K. Is Not Included in Travel Restrictions (Ingiltere, Seyahat Kısıtlamalarına Dahil Değil) \\
\hline Fotoğraf & İstanbul'daki Sultan Ahmet Camii \\
\hline Durum & $\begin{array}{l}\text { ABD Başkanı Donald Trump'ın coronavirüs ile mücadele bağlamında Avrupa'dan } \\
\text { ABD'ye seyahatleri } 30 \text { gün askıya alması haberin içeriğinde yer almaktadır. Ayrıca } \\
\text { İngiltere'nin bu durumdan muaf tutulduğu haberde dile getirilmektedir. }\end{array}$ \\
\hline $\begin{array}{l}\text { Sentaktik } \\
\text { Çözümleme }\end{array}$ & $\begin{array}{l}\text { Haberde edilgen çatılı cümleler kullanılmıştır. Hem basit hem } \\
\text { de bileşik cümleler haberde yer almaktadır. }\end{array}$ \\
\hline $\begin{array}{l}\text { Bölgesel } \\
\text { Uyum }\end{array}$ & $\begin{array}{l}\text { Haber içeriğinde New York Times, ABD Başkanı yönetimindeki beyaz sarayın virüse } \\
\text { yönelik tedbirlerini sıklaştırdığından ve çeşitliliği arttırdığından bahsedilmekte ve } \\
\text { daha sonra haberde Trump yönetiminin Schengen ülkelerini ve Avrupa'yı kapsayan } \\
\text { seyahat yasağı önlemini uygulamaya geçirdiğinde yer verilmektedir. }\end{array}$ \\
\hline $\begin{array}{l}\text { Sözcük } \\
\text { seçimleri }\end{array}$ & $\begin{array}{l}\text { Van Dijk'in eleştirel söylem analizinde ikincil kaynak olan editör tarafından kaleme alınan } \\
\text { bir haber içeriğidir. Lakin editörün içeriğe yönelik bir etkisinin olmadığı görülmektedir. }\end{array}$ \\
\hline $\begin{array}{l}\text { Haber } \\
\text { Retoriği }\end{array}$ & $\begin{array}{l}\text { Haber içeriğinde ABD yönetiminin virüse karşı almış olduğu tedbirlerin açık bir şekilde izah } \\
\text { edilmesi kamuoyu tarafından haberin güvenilirliği ve ikna edici boyutu tarafından önemli bir } \\
\text { kriterdir. Lakin haberde yer alan önlemler ve uçuş önemli alınan ülkeler arasında Türkiye'nin } \\
\text { olmamasına rağmen haberin servis edildiği görselde Türkiye'de yer alan Sultan Ahmet } \\
\text { Caminin kullanııması haberin retoriği bağlamında olumsuz bir gerçekliği ortaya koymaktadır. }\end{array}$ \\
\hline
\end{tabular}

Yukarıda çözümlemesi yapılmış olan haberde Beyaz sarayın Covid19 virüsüne yönelik almış olduğu "Schengen ülkelerini ve Avrupa'yı kapsayan seyahat yasağı" haberi İstanbul'daki Sultan Ahmet Camii görseli ile servis edilmiștir. Bu durum sanki Türkiye'nin de seyahat kısıtlamasına dâhil edildiği ve Türkiye'de de bir salgının olduğu algısının oluşturulmasına yönelik çabayı ortaya koymaktadır. Özellikle yerli yabancı çoğu turistin İstanbul ziyaretinde uğrak noktalarından biri olan Sultan Ahmet Camisin haber görselinde tercih edilmiş olması turistlerin dini sembolleri ziyaretini engellemeye yönelik bir çaba şeklinde okunabilir. 


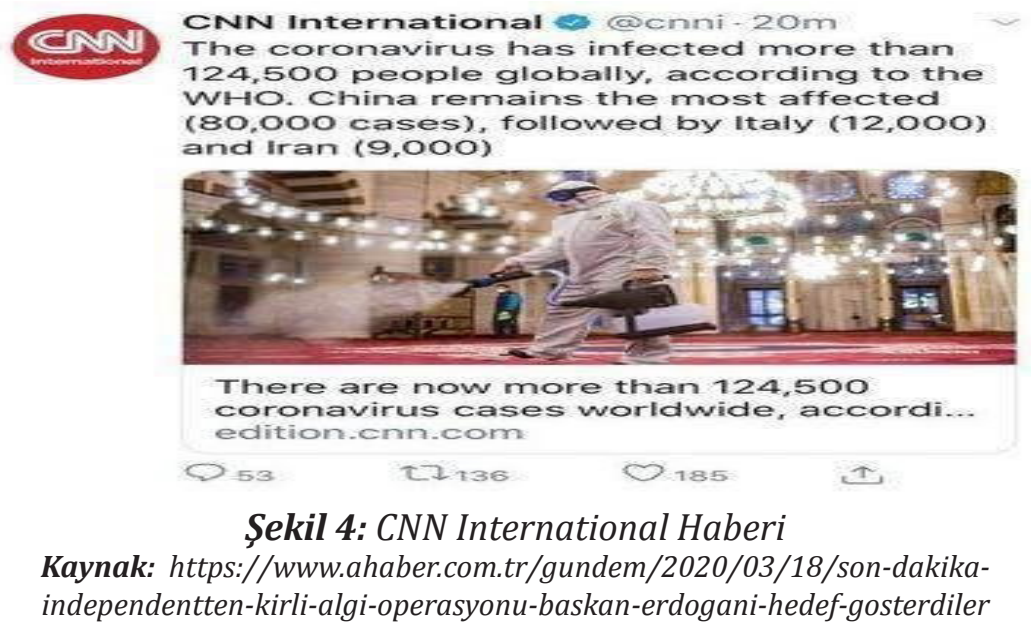

Tablo 4: CNN INTERNATIONAL Haberi Çözümlemesi

\begin{tabular}{|c|c|}
\hline Başlık & $\begin{array}{l}\text { The coronavirus has infected more than } 124,500 \text { people globally, according to the WHO. } \\
\text { China remains the most affected }(80,000 \text { cases), followed by Italy }(12,000) \text { and Iran }(9,000) \text {. } \\
\text { (Dünya Sağlık Örgütü'ne göre, koronavirüs küresel olarak } 124.500 \text { 'den fazla kişiye bulaştı. } \\
\text { En çok etkilenen Çin }(80.000 \text { vaka), ardından İtalya (12.000) ve İran }(9.000) \text { takip ediyor.) }\end{array}$ \\
\hline Haberin Girişi & $\begin{array}{l}\text { There are now more than } 124.500 \text { coronavirüs cases worldwide, according to the WHO (Dünya } \\
\text { Sağlık Örgütü'ne göre şu anda dünya çapında } 124.500 \text { 'den fazla coronavirüs vakası var) }\end{array}$ \\
\hline Fotoğraf & İstanbul'da bir cami \\
\hline Durum & $\begin{array}{l}\text { Haberde WHO’ya dayanarak o tarih itibariyle dünyada 124.500'den fazla vaka } \\
\text { olduğu belirtildikten sonra dünya genelindeki güncel vaka sayısı, ölüm sayısı, } \\
\text { virüsün bulaştığı ülke sayısı verilmiştir. Son kısımda ise vaka sayıları verilerek en } \\
\text { çok etkilenen ülkelerin sırasıyla Çin, İtalya ve İran olduğu belirtilmektedir. }\end{array}$ \\
\hline $\begin{array}{l}\text { Sentaktik } \\
\text { Çözümleme }\end{array}$ & Haberde edilgen çatılı cümleler kullanılmıştır. Haberde bileşik cümleler yer almaktadır. \\
\hline $\begin{array}{l}\text { Bölgesel } \\
\text { Uyum }\end{array}$ & $\begin{array}{l}\text { Haberde Covid-19 virüsü ile ilgili önce dünya ölçeğindeki toplam rakamlar } \\
\text { paylaşılmakta, daha sonra ülke bazında en yüksek vaka bulunan } 3 \\
\text { ülke (Çin, İtalya, İran) ile ilgili vaka bilgisi verilmektedir. }\end{array}$ \\
\hline $\begin{array}{l}\text { Sözcük } \\
\text { seçimleri }\end{array}$ & $\begin{array}{l}\text { Haber editör kaynaklı olup ikincil kaynak söz konusudur. Editör haberi } \\
\text { düzenlerken nötr davranmış, haberin içeriğine etki etmemiştir. }\end{array}$ \\
\hline $\begin{array}{l}\text { Haber } \\
\text { Retoriği }\end{array}$ & $\begin{array}{l}\text { Haber Dünya Sağlık Örgütü’ne dayandırılarak güvenilirliği sağlanmaya } \\
\text { çalışılmıştır. Ancak haberde içerikle ilgisi olmayan, Türkiye'den bir cami görseli } \\
\text { kullanımıştır. Bu durum bir algı yönetimi çabası görüntüsü vermektedir. }\end{array}$ \\
\hline
\end{tabular}

Yukarıda çözümlemesi yapılmış olan haber içeriğinde Covid19 virüsünün en çok etkilediği ülkelerin sırasıyla Çin, İtalya ve İran olduğu bilgisine yer verilmiştir. Haberin içeriğinde Türkiye ile ilgili bir bilginin yer almamasına rağmen haberin görselinde Türkiye'den bir Camii'nin görseline yer verilmesi virüsün Türkiye'de de var olduğu algısının yanı sıra Müslüman coğrafyanın kutsalı olan camilerin temizlikten uzak olduğu ve virüsün bulunduğu yerlerden olduğu algısı inşa edilemeye çalışılmıștır. 


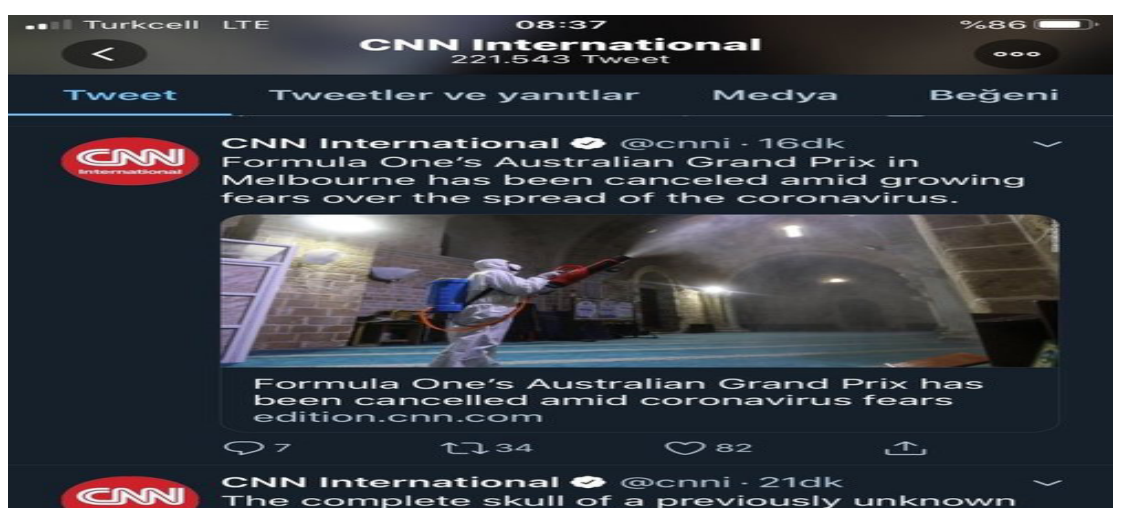

Şekil 5: CNN International Haberi

Kaynak: https://www.takvim.com.tr/guncel/2020/03/16/uluslararasi-medya-ve-turkiyedekiuzantilarindan-cirkin-algi-operasyonu-koronavirus-haberlerinde-ulkemizi-hedef-aldilar

Tablo 5: CNN INTERNATIONAL Haberi Cözümlemesi

\begin{tabular}{|c|c|}
\hline Başlık & $\begin{array}{l}\text { Formula One's Australian Grand Prix in Melbourne has been canceled amid growing fears over } \\
\text { the spread of the coronavirus. ( } \\
\text { Formula 1'in Melbourne'daki Avustralya Grand Prix'si, koronavirüsün } \\
\text { yayılmasından duyulan korkuların arasında iptal edildi.) }\end{array}$ \\
\hline Haberin Girişi & $\begin{array}{l}\text { Formula One's Australian Grand Prix has been cancelled amid coronavirus fears } \\
\text { (Formula 1'in Avustralya Grand Prix'si koronavirüs korkuları arasında iptal edildi) }\end{array}$ \\
\hline Fotoğraf & İstanbul'da bir cami \\
\hline Durum & $\begin{array}{l}\text { Haberde Avustralya Melbourne'de yapılacak Formula Grand Prix yarışmasının Covid-19 } \\
\text { virüsünün yayılması korkusuyla iptal edildiği, sezon açılışını iptal etme kararının, Avustralya } \\
\text { Grand Prix organizatörleri, Formula } 1 \text { ve motor sporlarının yönetim organı FIA tarafından } \\
\text { oybirliğiyle alındığı, kararı alanların sağlığı öncelediklerini belirten açıklamaları, McLaren } \\
\text { takımının bir üyesinin testinin pozitif çıkmasından sonra bu kararın alındığı belirtilmiştir. } \\
\text { Devamında McLaren'in konu ile tweeti verilmiştir. Arkasından } 7 \text { kişinin ve ayrıca } \\
\text { takımlarla ilgisi olmayan 9. bir kişinin testlerinin sonuçlarının beklendiği ifade edilmiştir. } \\
\text { Devamında } 6 \text { kez şampiyon olan Hamilton'ın Formula } 1 \text { ve FIA eleştirisine yer verilmiştir. } \\
\text { Hamilton içinde bulundukları duruma şaşırdığını, yarışmanın harika bir şey olduğunu } \\
\text { ancak hep beraber bir odada oturup beklemenin kendisini şok ettiğini ifade etmektedir. } \\
\text { Haberde son olarak bilet sahiplerinin ücret iade bilgilerinin beklendiği söylenmiştir. }\end{array}$ \\
\hline $\begin{array}{l}\text { Sentaktik } \\
\text { Çözümleme }\end{array}$ & $\begin{array}{l}\text { Haberde hem etken hem de edilgen çatılı cümleler kullanılmıştır. } \\
\text { Haberde basit ve bileşik cümleler yer almaktadır. }\end{array}$ \\
\hline $\begin{array}{l}\text { Bölgesel } \\
\text { Uyum }\end{array}$ & $\begin{array}{l}\text { Haberde sırasıyla önce iptal kararı ve karar vericilerin açıklamaları, arkasından } \\
\text { McLaren takımının açıklamaları, devamında şampiyon Hamilton'un karar vericilere } \\
\text { dönük eleştirileri ve son olarak ta bilet sahiplerine dönük bilgiler verilmiştir. }\end{array}$ \\
\hline $\begin{array}{l}\text { Sözcük } \\
\text { seçimleri }\end{array}$ & $\begin{array}{l}\text { Haber muhabir kaynaklı olup birincil kaynak söz konusudur. Muhabir haberi düzenlerken } \\
\text { karar alıcıların da onları eleştirenlerin de görüşlerine yer vermiştir. Ancak kendisinde } \\
\text { virüs çıkan bireyin McLaren takımından olduğunu belirtip McLaren'in resmi twitter } \\
\text { hesabının görüntüsünü habere yerleştirirken karar alıcıları eleştiren Hamilton'ın takımı } \\
\text { Mercedes'in ismini zikretmemesinin objektifliğe uygun olup olmadığı tartışmalıdır. }\end{array}$ \\
\hline Haber Retoriği & $\begin{array}{l}\text { Haberde Formula 1'in Covid-19'un yayılması korkuları arasında iptal edildiğini } \\
\text { söyleyerek başlaması iğneleyici görünmektedir. Devamında karar alıcıların ve } \\
\text { onları eleştiren yarışmacının ifadelerine yer verilmesi ile bir dengeleme yapııldığı } \\
\text { görülmektedir. Bu durum haberin objektifliği açısından önemli bir kıstas olmuştur. Lakin } \\
\text { bu haberin içeriğinde Türkiye'den bir caminin temizlenmesi görseline yer verilmesi } \\
\text { objektif bir tavrın reddi niteliğinde olmakla beraber güvenilirliği düşürmektedir. }\end{array}$ \\
\hline
\end{tabular}

Yukarıda çözümlemesi yapılmış olan haberin içeriğinde Avustralya Melbourne'de yapılacak Formula Grand Prix yarışmasının Covid-19 virüsünün yayılması korkusuyla iptal edildiği bilgisine yer verilmiștir. Haberin görselinde ise Türkiye'den bir caminin kullanılmıș olması virüsün Türkiye'de de bulunduğu algısının inșa edilmek istenmesinin yanında kamuoyuna yönelik olarak Müslümanlar ile Covid-19 virüsü arasında bir bağ kurdurulması arzusu șeklinde okunabilir. 


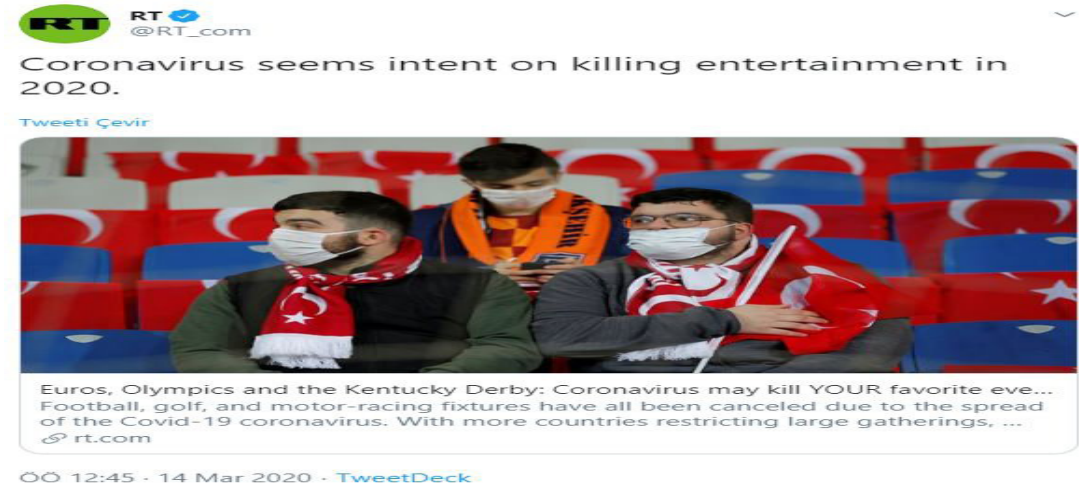

Şekil 6: Russia Today Haberi

Kaynak: https://www.sabah.com.tr/dunya/2020/03/14/son-dakika-nyt-ve-bbcdensonra-rus-medyasindan-da-coronavirus-algisi-turkiye-fotografi-kullandilar

Tablo 6: Rusia Today Haberi Çözümlemesi

\begin{tabular}{|c|c|}
\hline Başlık & $\begin{array}{l}\text { Coronavirus seems intent on killing entertainment in 2020. (Coronavirus, } \\
2020 \text { 'de eğlenceyi öldürmeye niyetli gibi görünüyor.) }\end{array}$ \\
\hline Haberin Girişi & $\begin{array}{l}\text { Euros, Olympics and the Kentuky Derby: Coronavirus may kill } \\
\text { YOUR favorite event NEXT. (Eurolar, Olimpiyatlar ve Kentuky Derbisi: } \\
\text { Coronavirus SiZiN favori etkinliğinizi YAKINDA öldürebilir) }\end{array}$ \\
\hline Fotoğraf & $\begin{array}{l}\text { 12.03.2020 tarihinde İstanbul'da oynanan Başakşehir- Copenhagen } \\
\text { UEFA Avrupa Ligi Son } 16 \text { Turu karşılaşması tribününden bir kare }\end{array}$ \\
\hline Durum & $\begin{array}{l}\text { Haberde futbol, golf ve motor yarışı fikstürlerinin Covid-19 koronavirüsünün yayılması } \\
\text { nedeniyle iptal edildiğini, McLaren tamircisi Covid-19 (koronavirüs) testinin pozitif çıkması } \\
\text { sonrasında Formula } 1 \text { Avustralya Grand Prix'inin iptal edildiğini belirtmektedir. Grand } \\
\text { Prix'in, dünya çapında 145.000'den fazla ölümcül koronavirüs vakası ve 5.400'den } \\
\text { fazla ölüm olduğu için, son haftalarda baltalanan birçok spor fikstürünün en yenisi } \\
\text { olduğu, İngilterède, Premier Lig'in ertelenmesi konusunda bir acil durum toplantısı } \\
\text { düzenleneceği, UEFA'nın tüm Şampiyonlar Ligi ve Avrupa Ligi maçlarını askıya aldığı, } \\
\text { Beş Avrupa golf turnuvasının iptal edildiği, tüm Six Nations ragbi oyunları iptal edildiği ve } \\
\text { MotoGP yarışlarının ertelendiği ifade edilmektedir. Yine NBA, NHL, MLS'nin oyunlarının } \\
\text { askıya alındığı ve ATP tenis turnuvasının da iptal edildiği vurgulanmaktadır. }\end{array}$ \\
\hline $\begin{array}{l}\text { Sentaktik } \\
\text { Çözümleme }\end{array}$ & $\begin{array}{l}\text { Haberde ağırlıklı olarak edilgen cümleler kullanılmıştır. Haberde } \\
\text { bileşik cümleler de yoğunluk göstermektedir. }\end{array}$ \\
\hline $\begin{array}{l}\text { Bölgesel } \\
\text { Uyum }\end{array}$ & $\begin{array}{l}\text { Haberde sırasıyla çeşitli spor organizasyonlarının covid19 sebebi ile iptal } \\
\text { edildiği ifade edilerek bu organizasyonların bir kısmı zikredilmektedir. }\end{array}$ \\
\hline $\begin{array}{l}\text { Sözcük } \\
\text { seçimleri }\end{array}$ & $\begin{array}{l}\text { Haber editör kaynaklı olup ikincil kaynak söz konusudur. Haberin ilk paragrafında } \\
\text { "birçok ülke büyük toplantıları kısıtlarken kesme bloğunda sırada ne var" sorusu } \\
\text { ile olumsuz olan bu gelişmelerin devam edeceği izlenimi uyandırmıştır. }\end{array}$ \\
\hline Haber Retoriği & $\begin{array}{l}\text { Haberin içeriğinde virüs bağlamında iptal edilen spor organizasyonlarının detaylarına yer } \\
\text { verilmesi güvenilirlik ve ikna edicilik bağlamında önemli bir ölçüt iken haberin görselinde hiçbir } \\
\text { yerde ismi geçmeyen Türkiye'de oynanan Başakşehir- Copenhagen futbol müsabakasından } \\
\text { bir fotoğrafın kullanılması haberin güvenilirliğine gölge düşüren bir unsur olmuştur. }\end{array}$ \\
\hline
\end{tabular}

Yukarıda çözümlemesi yapılmış olan haberde corona virüsten ötürü önemli spor organizasyonlarının iptal edildiği ve iptal edilmeye devam edeceği bilgisi yer almaktadır. Lakin haberde yer alan görselde virüsün daha önceden görülmüş olduğu ülkelerin henüz spor müsabakalarının iptali edilmemesine rağmen virüsün 3.gününü yaşıyor olan Türkiye'den geçmiş tarihte oynanan Başakşehir- Copenhagen müsabakasından bir görselin tercih edilmiş olması dünya genelinde spor müsabakaları iptal edilirken Türkiye'de devam ettiği ve virüsün önemsenmediği algısının inşa edilmeye çalışılması şeklinde bir okunabilir. 


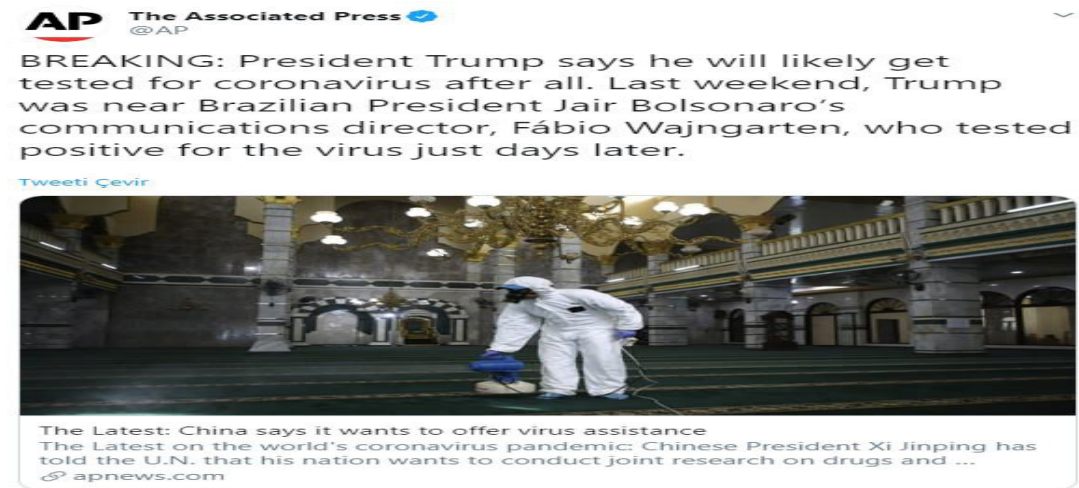

SSekil 7: The Assoctiated Press Haberi

Kaynak: https://www.sabah.com.tr/dunya/2020/03/14/son-dakika-nyt-ve-bbcdensonra-rus-medyasindan-da-coronavirus-algisi-turkiye-fotografi-kullandilar

Tablo 7: The Associated Press Haberi Cözümlemesi

\begin{tabular}{|c|c|}
\hline Başlık & $\begin{array}{l}\text { The latest: China says it wants to ofter virüs assistance (Son Durum: } \\
\text { Çin, virüs araştırması için destek vermek istediğini söyledi). }\end{array}$ \\
\hline Haberin Girişi & $\begin{array}{l}\text { Breakıng: president Trump says he will likely get tested for coronavirus after all. Last } \\
\text { weekend, Trump was near Brazilian President Jair Bolsonaro's Communications director, } \\
\text { Fabio Wajngarten, who tested positive for the virus just days later ( Başkan Trump, } \\
\text { muhtemelen koronavirüs için kendisine test yapılacağını söyledi. Geçen hafta sonu, } \\
\text { Trump Brezilya Cumhurbaşkanı Jair Bolsonaro'nun İletişim Direktörü Fabio Wajngarten } \\
\text { beraberdi ve birkaç gün sonra Fabio'nın virüs için yaptırdığı test pozitif çıktı). }\end{array}$ \\
\hline Fotoğraf & Türkiye'de bulunan ve temizlik yapılan bir camiinin görseli kullanılmıştır. \\
\hline Durum & $\begin{array}{l}\text { Amerikan haber ajansı The Associated Press (AP) haberinde, Başkan Trump'ın } \\
\text { koronavirüs testi yaptıracağı haberinde Amerika Başkanı Donalp Trump'ın koronavirüs } \\
\text { testi yaptıracağını haberleştirdi. Haberde; Trump'ub, Brezilya Cumhurbaşkanı Jair } \\
\text { Bolsonaro'nun İletişim Direktörü Fábio Wajngarten'ın yakınında olduğu ve Waajngarten'in } \\
\text { birkaç gün sonra koronavirüs testinin pozitif çıktığı yer aldı. Haberin detaylarında Brezilya } \\
\text { Cumhurbaşkanının en büyük oğlu için düzenlediği doğum günü partisine katılan ABD } \\
\text { Başkanı Trump'la İletişim Direktörü Wajngarten'ın fotoğraf çektirdiği ve ikilinin birbirinin } \\
\text { elini sıktığı belirtildi. Aynı zamanda haberde Beyaz Saray doktorunun Cuma gecesindeki } \\
\text { mektubunda, "herhangi bir belirti başlamadan önce tüm etkileşimler gerçekleştiği } \\
\text { için” Beyaz Saray “düşük riskli” olarak değerlendirdiğine de yer verilmiştir. }\end{array}$ \\
\hline $\begin{array}{l}\text { Sentaktik } \\
\text { Çözümleme }\end{array}$ & $\begin{array}{l}\text { Haberin içeriğinde genel anlamda etken çatılı cümlelerin kullanıldığı (görüşüldü ve } \\
\text { yapıldı gibi) bunun yanı sıra basit yapıdaki cümlelere yer verildiği görülmektedir. }\end{array}$ \\
\hline $\begin{array}{l}\text { Bölgesel } \\
\text { Uyum }\end{array}$ & $\begin{array}{l}\text { Brezilya Cumhurbaşkanı Jair Bolsonaro'nun İletişim Direktörü Fábio Wajngarten'ın virüs } \\
\text { testinin pozitiv çıktığı bu sebeple ABD Başkanının da test yaptıracağının belirtildiği } \\
\text { haberde daha sonra Columbia Üniversitesinden yetkililerin açıklamalarına ve beyaz } \\
\text { saray doktorunun konuya yönelik söylemlerine yer verilmiştir. Bu durum haber metni } \\
\text { içerisinde bir ilişkiselliğin yani neden sonuç ilişkisinin olduğunun göstergesidir. }\end{array}$ \\
\hline $\begin{array}{l}\text { Sözcük } \\
\text { Seçimleri }\end{array}$ & $\begin{array}{l}\text { Van Dijk'in eleştirel söylem analizinde ikincil kaynak olan editör tarafından kaleme alınan } \\
\text { bir haber içeriğidir. Lakin editörün içeriğe yönelik bir etkisinin olmadığı görülmektedir. }\end{array}$ \\
\hline $\begin{array}{l}\text { Haber } \\
\text { Retoriği }\end{array}$ & $\begin{array}{l}\text { Haberin içeriğinde ABD Başkanına test yapılması gerektiğinin vurgulanması ve bunun } \\
\text { dayandırıldığı noktanın da Trump'ın } 73 \text { yaşında olmasından ötürü olduğunun belirtilmesi } \\
\text { ve yakın temas sağlandığı için hemen önlem alınması için harekete geçilmesi Beyaz } \\
\text { saray yönetiminin meseleye verdiği önem bakımından kamuoyu tarafından ikna edici } \\
\text { bulunabilir. Lakin haberde hiçbir şekilde ismi zikredilmeyen Türkiye'ye ait bir görselin } \\
\text { kullanılması bu görselinde Müslüman coğrafyanın kutsal değeri olan ibadethaneye yani } \\
\text { camiye ait olması haberin doğruluğu ve tarafsızlığı üzerine gölge düşürmüştür. }\end{array}$ \\
\hline
\end{tabular}

Yukarıda çözümlemesi yapılmış olan haberde ABD başkanının Brezilya Cumhurbaşkanı Jair Bolsonaro'nun İletişim Direktörü Fabio Wajngarten ile temas etmesi ve Wajngarten'de Covid19 testinin pozitif çıkması sonucunda ABD başkanının da test yaptıracağı bilgisi yer almaktadır. Haberin içeriği ile kullanılan görsel değerlendirildiğinde haber içeriğinde hiçbir şekilde ismi geçmeyen Türkiye'den Müslüman coğrafyanın kutsal değeri olan 
ibadethaneye yani camiye ait olması batı dünyasında Müslüman coğrafyaya ve değerlere yönelik oluşturulmak istenen bir algı şeklinde okunabilir.

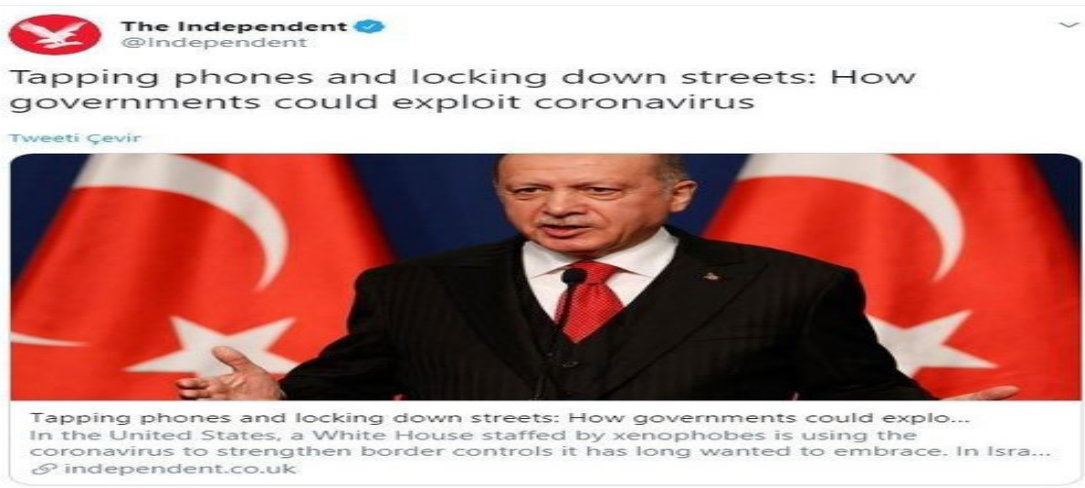

Sekil 8: The Independent Haberi

Kaynak: https://www.ahaber.com.tr/gundem/2020/03/18/son-dakikaindependentten-kirli-algi-operasyonu-baskan-erdogani-hedef-gosterdiler

Tablo 8: The Independent Haberi Çözümlemesi

\begin{tabular}{|c|c|}
\hline Başlık & $\begin{array}{l}\text { Tapping phones and locking drow streets: How governments could } \\
\text { exploit coronavirus (telefonları dokunulduğunda ve drow sokaklar } \\
\text { kilitleme: hükümetler coronavirüs'den nasıl yararlanabilir) }\end{array}$ \\
\hline Haberin Girişi & $\begin{array}{l}\text { Coronavirus could be used by authoritarian leaders as excuse to undermine } \\
\text { democracy, experts warn (Coronavirus, otoriter liderler tarafından } \\
\text { demokrasiyi baltalamak için bir bahane olarak kullanılabilir). }\end{array}$ \\
\hline Fotoğraf & $\begin{array}{l}\text { Haberin sunumunda Türkiye Cumhuriyeti'nin Cumhurbaşkanı Recep Tayyip Erdoğan'ın } \\
\text { Başkanlık sarayında bir açıklama yaparken çekilmiş olan bir görsel kullanılmıştır. }\end{array}$ \\
\hline Durum & $\begin{array}{l}\text { Koronavirüse karşı hükümetlerin aldığı önlemleri aktaran İndependent, ABD, İran, Macaristan, } \\
\text { Irak, Cezayir, Lübnan, İsrail, Romanya, Ürdün, İspanya, Fransa ve Almanya gibi ülkeler ile ilgili } \\
\text { detaylı açıklamalara yer verdiği haberinde İsrail ve Singapur'un GPS yoluyla vatandaşlarını takip } \\
\text { edeceği bilgisine de yer verirken manşet görselinde ise Türkiye Cumhuriyeti'nin Cumhurbaşkanı } \\
\text { Recep Tayyip Erdoğan'ı kullanıyor. Haberde yer alan diğer ifadelerde ise Türkiye'nin koronavirüs } \\
\text { için lüks alışveriş merkezlerini açık tutarken alkol kullanılan mekânların kapatıldığı ifade edilerek } \\
\text { bir algı oluşturulmaya çalışıyor. Lakin haberin yayınlandığı zaman diliminde önlemler kapsamında } \\
\text { Türkiye'de cemaatle namaz kılınmasını geçici olarak askıya aldığı bilgisine ise yer verilmiyor. }\end{array}$ \\
\hline $\begin{array}{l}\text { Sentaktik } \\
\text { Çözümleme }\end{array}$ & $\begin{array}{l}\text { Haberin içeriğinde genel manada etken çatılı cümlelerin kullanıldığı } \\
\text { (önlemler alındı ve çalışmalar yapıldı gibi) bunun yanı sıra basit ve bileşik } \\
\text { yapıdaki cümlelere de aynı oranda yer verildiği görülmektedir. }\end{array}$ \\
\hline $\begin{array}{l}\text { Bölgesel } \\
\text { Uyum }\end{array}$ & $\begin{array}{l}\text { Haberde İran ve Macaristan'da virüse karşı alınan önlemler izah edilmekte sonrasında } \\
\text { sırasıyla ABD, Irak, Cezayir, Lübnan, İsrail, Romanya, Ürdün, İspanya, Fransa, Almanya } \\
\text { ve Türkiyede virüse karşı alınan önlemlerden bahsediliyor. İspanya ve Fransa'da yaşanan } \\
\text { durumun son derece kritik ve ürkütücü olduğu ifade edilirken Michigan Eyalet Üniversitesi } \\
\text { ve Beyrut Amerikan Üniversitesinden akademisyenlerin virüse karşı öngörülerine yer } \\
\text { verilmiştir. Felaket durumu olarak adlandırılan bu süreç ile ilgili haberin genel özetinin } \\
\text { "Siyaset bilimciler, krizler bazen insanları bir araya getirip ortak bir amaç için birleştirirken, } \\
\text { otoriter liderlere uzun zamandır aksi takdirde isteksiz olan insanlara istedikleri politikaları } \\
\text { dayatma fırsatı sunduklarını söylüyorlar" şeklinde olduğu haberde yer almaktadır. }\end{array}$ \\
\hline $\begin{array}{l}\text { Sözcük } \\
\text { Seçimleri }\end{array}$ & $\begin{array}{l}\text { Van Dijk'in eleştirel söylem analizinde birincil kaynak olarak ifade ettiği } \\
\text { muhabirin ve aynı zamanda ikincil kaynak olan editörün haber içeriğinin } \\
\text { hazırlanma sürecinde etkisinin olduğu görülmektedir. Haberde muhabirin } \\
\text { ve editörün kendi düşüncelerinin de yer bulduğu görülmektedir. }\end{array}$ \\
\hline $\begin{array}{l}\text { Haber } \\
\text { Retoriği }\end{array}$ & $\begin{array}{l}\text { Haberin içeriğinde birçok ülkede virüse karşı alınan önlemlerden bahsediyor olsa da, } \\
\text { her ülke kendi içerisinde birçok geniş kapsamlı önlemler almasına rağmen çok küçük } \\
\text { bir kısmına yer verilmesi haberin detaylı ve kapsamlı bir haber olmadığı izlenimini } \\
\text { oluşturmaktadır. Aynı zamanda muhafazakâr İslamcı kökenli hükümet olarak adlandırılan } \\
\text { Türkiye Cumhuriyeti Hükümetinin alkollü mekanları kapattığına yönelik bir önlemden } \\
\text { bahsedilirken alışveriş merkezlerinin açık olduğunun ifade edilmesi bunun yanı sıra } \\
\text { camilerde toplu halde ibadet edilmesinin bir süre açığa alındığı şeklindeki bir önlemden } \\
\text { hiç bahsedilmemesi haberin güvenilirliğinin sorgulanmasını gerektirmektedir. }\end{array}$ \\
\hline
\end{tabular}


Yukarıda çözümlemesi yapılmış olan haberde Covid19 virüsüne yönelik olarak hükümetlerin aldıkları tedbirlere yer verilmiștir. Türkiye'ye yönelik bölümde sadece lüks alışveriş merkezlerini açık tutarken alkol kullanılan mekânların kapatıldığı ifade edilmiştir. Lakin Türkiye Cumhuriyeti Cumhurbaşkanı Recep Tayyip Erdoğan'ın 30 Ocak 2020 tarihinde virüse karşı alınan ve alınacak olan önlemleri açıklamış olduğu ve virüsün Türkiye'de ilk olarak 11 Mart 2020 tarihinde görülmüş olduğu gerçeği göz ardı edilerek Türkiye hükümetinin başarısı gölgelenmek istendiği gibi Türkiye'de virüsün önemsenmediği algısı inşa edilmeye çalışılmıştır. Aynı zamanda Recep Tayyip Erdoğan hükümetini muhafazakâr İslamcı kökenli bir hükümet şeklinde tanımlayıp alkollü mekânların kapatıldığı dönemde camilerde toplu halde ibadet edilmesinin de bir süre askıya alındığı gerçeği göz ardı edilerek kendi halkı içerisinde bir taraf olduğu ve ötekileştirme yaptı̆̆ı algısı inşa edilmeye çalışılmıştır.

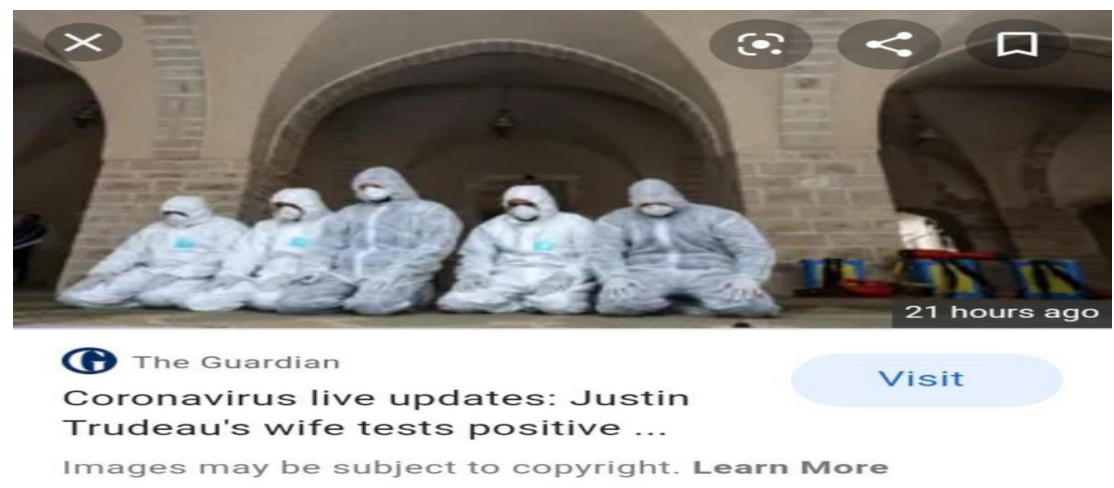

SSekil 9: The Guardian Haberi

Kaynak: https://www.takvim.com.tr/guncel/2020/03/16/uluslararasi-medya-ve-turkiyedekiuzantilarindan-cirkin-algi-operasyonu-koronavirus-haberlerinde-ulkemizi-hedef-aldilar

Tablo 9: The Guardian Haberi Çözümlemesi

\begin{tabular}{|l|l|}
\hline Başlık & $\begin{array}{l}\text { Coronavirus Live Updates: Justin Trudeau's Wife Tested Positive (Coronavirus } \\
\text { Son Durum: Justin Trudeau'nun Karısı Test Sonucu Pozitif Çıktı) }\end{array}$ \\
\hline Haberin Girişi & $\begin{array}{l}\text { The wife of Canadian prime minister Justin Trudeau has tested positive for Covid-19 } \\
\text { following a trip to the United Kingdom. (Kanada başbakanı Justin Trudeau'nun eşinin, } \\
\text { Birleşik Krallık'a yaptığı geziden sonra Covid-19 için yaptırdığı test pozitif çıktı). }\end{array}$ \\
\hline Fotoğraf & $\begin{array}{l}\text { Türkiye'de yer alan bir camide temizlik çalışmaları yapan } \\
\text { personellerin namaz kıldığı bir görsel paylaşılmıştır. }\end{array}$ \\
\hline Durum & $\begin{array}{l}\text { Haberin içeriğinde Başbakanın virüsün rahatsı edici semptomlarını yaşıyor olmama } \\
\text { rağmen, yakında ayakta olacağım dediğine ve evde karantinaya girmek daha ciddi } \\
\text { sağlık sorunlarıyla karşılaşanlara kıyasla hiçbir şey değil söylemlerine yer verilmiştir. } \\
\text { Ayrıca Başbakanın görevine sağlıklı ve semptomsuz bir şekilde dönüşünün iki } \\
\text { hafta süreceği ve bu süreçte uzaktan çalışmalarına devam edeceği son olarak } \\
\text { da cuma günü Kanada halkına hitap etmesinin beklenildiği yer almaktadır. }\end{array}$ \\
\hline $\begin{array}{l}\text { Sentaktik } \\
\text { Ç̈zz̈mmleme }\end{array}$ & $\begin{array}{l}\text { Haberin içeriğinde genel manada etken çatılı cümlelerin kullanılığı bunun } \\
\text { yanı sıra basit yapıdaki cümlelere de yer verildiği görülmektedir. }\end{array}$ \\
\hline Bölgesel & $\begin{array}{l}\text { Haberde Kanada Başbakanının eşine Birleşik Krallığa yapmış olduğu ziyaret } \\
\text { dönüşünde yapılan Covid19 testinin pozitif çıtığından bahsedilirken sonrasında } \\
\text { Başbakanın konuya dair açıklamalarına yer verilmiştir. Daha sonra Kanada hükümeti } \\
\text { Olarak tedbir almaya devam ettiklerini ve kurallara daha çok uyularak süreçten en } \\
\text { kısa zamanda en az hasarla çıkılacağına dair açıklamaları yer almaktadır. Haber } \\
\text { metninin içeriğinde cümlelerin arasında bir ilişkiselliğin olduğu görülmektedir. }\end{array}$ \\
\hline $\begin{array}{l}\text { Sözcük } \\
\text { Seçimleri }\end{array}$ & $\begin{array}{l}\text { Van Dijk'in eleştirel söylem analizinde ikincil kaynak olarak adlandırdığı editörün } \\
\text { haber içeriğinin hazırlanma sürecinde etkisinin olduğu görülmektedir. Endişeler } \\
\text { var, korkuluyor ve önlemler acil alınmalı şeklinde editörün kaleminden kendi } \\
\text { düşüncelerini izah eden bir haberin kaleme alındığı görülmektedir. }\end{array}$ \\
\hline
\end{tabular}




\begin{tabular}{|l|l|}
\hline & $\begin{array}{l}\text { Haberde Kanada Başbakanının kendi ifadelerine yer verilmesi ve aynı zamanda } \\
\text { sayısal anlamda virüsün ülke genelindeki halinin ortaya konulması bakımından haber }\end{array}$ \\
Haber & güvenilirliği sağlayabilecek bir durumdadır. Lakin haberin başı̆̆ından içeriğinde yer \\
Retoriği & $\begin{array}{l}\text { alan metine kadar kullanılan tüm argümanlar da Türkiye'nin ismi bir defa dahi hiçbir } \\
\text { yerde geçmez iken haberin servis edildiği görselde Türkiye'de yer alan bir caminin } \\
\text { olması haberin güvenilirliği ile ilgili çok önemli bir soru işaretini ortaya koymaktadır. }\end{array}$ \\
\hline
\end{tabular}

Yukarıda çözümlemesi yapılmış olan haberin içeriğinde Kanada Başbakanının eşinin Covid19 testinin pozitif çıktığı yer almaktadır. Lakin haberin içeriğinde yer alan metinde Türkiye'nin ismi hiçbir yerde geçmez iken haberin servis edildiği görselde Türkiye'de yer alan bir caminin kullanılması ve virüsle mücadele haberinde namaz kılan kişilerin gösterilmesi ile sanki bu ibadetin virüs önleme de bir yöntem gibi kullanıldığı algısı oluşturarak dini ritüeller hafife alınmıștır.

\section{Sonuç}

Yaşamış olduğumuz çağa ismini veren dijital kavramının medyaya uyarlanmış hali olan dijital medyanın günümüzdeki önemi yadsınamaz bir şekilde kabul görmektedir. Yaşanan teknolojik gelişmelerin toplumsal dünyada fazlası ile karşılık bulması neticesinde kitleler bilgi bombardımanı ile karşılaşmakta ve bu bilgi havuzunun arka planına dair doğru okuma yapmakta zorlanmaktadır. Yaşanan bu hızlı gelişmeler ve dönüşümler doğruluğu teyit edilmekte zorlanılan birçok enformasyonun yayılmasına sebep olmakta ve bir bilgi karmaşası ortaya çıkarmaktadır. Toplumsal yapı içerisindeki bireylerin günlük hayat pratikleri içerisinde neyi ön planda tutup neyi göz ardı edeceğine yani nelerin gündeminde yer alacağına bu gelişmelerin neticesi olan dijital medya platformları ve bu platformları elinde bulunduran güç odakları karar vermektedir. Bu karar mekanizmasının istemsiz bir şekilde veyahut farkında dahi olunmadan bu güç odaklarına verilmiş olması hayata dair doğru okumaları yapmanın önündeki en büyük engellerden birini teşkil etmektedir.

Medyaya yönelik inisiyatifi elinde bulunduranlar tarafından kamuoyunu bilgilendirmek amacı ile sunulan haber içerikleri ile toplumsal, kültürel, siyasal ve ekonomik gerçeklik dışında bir medya gerçekliği ortaya konmakta ve genel manada bu üretilen gerçeklik asıl gerçekliğin yerine geçirilerek arzu edilen şekilde inşa edilmiş olan sanal gerçeklik kamuoyuna sunulmaktadır. Haber içeriklerinde kurgulanan bu gerçeklikte medyanın mülkiyet yapısı önemli bir rol oynamaktadır. Bu bağlamda düşünüldüğünde medyanın salt gücünü elinde bulunduranların temel hedefi algı yönetimi tekniklerini uygulamaya geçirerek kamuoyuna kurguladıkları içerikleri en doğru kanallar aracılığıyla iletmek ve kamuoyunun istenen amaca doğru yönelmelerini sağlanmaktır.

Medya, gerçekliği arzu edilen şekilde kurgulayıp kamuoyuna yansıtabilmekte ve bu şekilde hedef kitle üzerinde bir manipülatif etki inşa edebilmektedir. Medyada "dezenformasyon" olarak isimlendirilen bu durum yanlıș veyahut doğruluğu bulunmayan bir kurmaca gerçekliğin kamuoyuna aktarımının temsilidir. Manipülatif etki oluşturmak amacı ile yapılan paylaşımlar kişisel bazda gelişigüzel bir şekilde gerçekleștirilebileceği gibi topluluklar, gruplar veyahut da örgütler tarafından da sistemli bir șekilde yapılabilir.

Algı yönetiminin kurgulanan bir içeriğin kamuoyu tarafından kabul görmesine yönelik tarafı günümüz dijital medya dünyasının olmazsa olmazı durumundadır. Bu algı yönetimi gerçekleştirilirken iletişim ve medya bağlamında bir profesyonel algı yönetimine fazlası ile ihtiyaç vardır. Günümüz dünyasında ciddi bir mücadeleye dayanan ve artık tamamen algı savaşlarına dönüşen küresel rekabet ortamı gerek ülkeler ve toplumlar arası iletişimi, gerekse ülke içindeki ulusal dengeleri yakından etkilemektedir. 
Ülkelerin kendi aralarındaki siyasi dengelerinin medyalarına da yansıdığı görülmekte, dost düşman ayrımına göre haber içeriklerinde manipülasyonlar yapılabilmektedir. $\mathrm{Bu}$ araștırmanın bulguları neticesinde bir süredir batı ülkeleri ile gerilimli ilişkileri olan Türkiye'nin batı medyasında hedef haline getirildiği görülmüștür. Buna batı dünyasında son dönemde iyice yükselen İslamofobi ve milliyetçilik dalgalarının etkisi de eklendiğinde Türkiye'nin ötekileştirilmesi daha da dikkat çekici hale gelmektedir. Nitekim bazı haber görsellerinde cami kullanılmakla beraber bu camilerin aynı zamanda Türkiye'den seçilmiş olması algı yönetiminde çift etki üretilmesi (İslamofobi ve Türkiye karşıtlığı) çabasını gözler önüne sermektedir. Küresel siyasette son yıllarda alternatif söylem üretme gücü ile dikkat çeken Türkiye'nin hedef tahtasına oturtulması hem Türkiye'nin uluslararası imajını zedeleme hem de kendi kamuoylarında düşman algısı üzerinden bir konsolidasyon sağlama çabası ile açıklanabilir.

Çin'in Wuhan kentinde ortaya çıkan ve tüm dünyayı etkisi altına alan Covid-19 krizini çalışmada incelenen haberlerin yapıldığı dönemde ağır yoğunluklu geçiren ülkelerin başında İtalya, İspanya, ABD, Çin ve Fransa gelmektedir. Bu süreçte Türkiye ise virüs vakasının görüldüğü ilk günden itibaren virüsün yoğun bir şekilde devam ettiği ülkelere yönelik uçuş yasağı getirmek, okulları tatil ederek uzaktan eğitim modeline geçmek, toplu bir şekilde bulunma mekânlarını bir süreliğine kapatıp mobilize olma durumunu asgari seviyelere çekmek gibi durumu kontrol altına almaya yönelik önlemlerini hayata geçirmiştir. Lakin tüm bu gerçeklere rağmen Covid19 küresel salgını tüm dünya medyasının öncelikli gündemi iken batı medyasının bu durumu hem dikkatleri kendi ülkelerinden uzaklaştırma hem de İslamofobi ve Türkiye karşıtlığı için bir manipülasyon aracı olarak kullanma çabasında olduğu ve Batı dünyasının Türkiye'ye karşı patolojik tutumunu sürdürmekte olduğu gerçeği yapılan bu çalışma ile gözler önüne konmaktadır.

\section{Kaynakça}

Akarsu, B. (1984). Felsefe Terimleri Sözlüğü, Gerçek Maddesi. Ankara: Savaş Yayınları.

Altun, S. (2007). Haber söylemi, değişkeleri: Cumhuriyet mitingleri ya da gelincik devrimi örneklemi. Yayımlanmamış yüksek lisans tezi, İstanbul Kültür Üniversitesi Sosyal Bilimler Enstitüsü, İstanbul.

Atabek, N. (2003). Propaganda ve Toplumsal Kontrol. Selçuk Üniversitesi İletişim Fakültesi Akademik Dergisi, 2(4), 4-12.

Aydınalp, H. Ş. (2019). Sosyal medyada manipülasyon : pkk tarafından oluşturulan haberler üzerine bir inceleme. İstanbul: Marmara Üniveristesi.

Babacan, M. E., Haşlak, İ., \& Hira, İ. (2011). Sosyal Medya ve Arap Baharı. Akademik Incelemeler Dergisi, 6(2), 71.

Baudrillard, J. (2018). Simülarkrlar ve Simülasyon (12 b.). (O. Adanır, Çev.) Ankara: Doğu Batı Yayınları.

Bozkurt, H. (2012). Gelişen Teknoloji İle Değişen Gazetecilik Mesleği. İstanbul: İstanbul Üniveristesi Sosyal Bilimler Enstitüsü.

Chomsky, N. (2002). Medya Gerçeği. (A. Yılmaz, \& O. Akınhay, Çev.) İstanbul: Everest Yayınları.

Çınarlı, İ. (2004). Döngü Uzmanları (Spin Doctors) Medyatik Yalan ve Kamu Manipülasyon. Galatasaray Üniversitesi İletişim Dergisi(1), 169-170. 
Demirel, S. D. (2018). Dijital medyada haber üretim sürecinde okuyucu odaklılık. Journal of International Social Research, 11(55), 824-831.

Dursun, Ç. (2003). Haber ve Habercilik Üzerine Düşünmek. S. Alankuş içinde, Gazetecilik ve Habercilik (s. 63-83). İletişim Vakfı Yayınları.

Eraslan, L. (2018). Sosyal Medya ve Algı Yönetimi: Sosyal Medya İstihbaratına Giriş. Ankara: Anı Yayıncilık.

Erol, S. M., \& Ozan, E. (2014). Türk Dış Politikasında Algı Yönetimi. (B. Karabulut, Dü.) İstanbul: Alfa Yayımcılı.

Hall, S. (2014). İdeoloji ve İletişim Kuramı. S. İrvan içinde, Medya Kültür Siyaset (A. Gürata, Çev., s. 79-97). Ankara: Pharmakon Yayınları.

Karabulut, B. (2014). Algı Yönetimi. İstanbul: Alfa Yayınevi.

Kellner, D. (2004). 9/11 Spectacles of Terror and Media Manipulation. Critical Discourse Studies , 41-64.

Kocabaşoğlu, U. (1977). Haber Kavramı Üzerine. A.Ü. BYYO YILLIK(1974/1976), 335-349.

Liang, X., \& Wei, W. (2020). Institutionalization in News Translation: The Use and Abuse of Manipulation. Language Research in Multilingual Settings, 71-93.

Manor, I. (2018). how diplomats can combat digital propaganda. 3 15, 2020 tarihinde alındı

Mora, N. (2011). Medya Çalışmaları Medya Pedagojisi ve Küresel İletişim. Ankara: Nobel Yayınları.

Morgan, S. (2018). Fake News, Disinformation, Manipulation and Online Tactics To Undermine Democracy. Journal of Cyber Policy, 39-43.

Mumford, L. (1996). Makina Efsanesi. (F. Oruç, Çev.) İstanbul: İnsan Yayıncılık.

Murdock, G. (1980). Class, Power and The Press: Problems of Conceptualization and Evidence. (H. Crition, Dü.) The Sociology of Journalism and the Press, 39-57.

Öksüz, H. (2013). Algı Yönetimi ve Sosyal Medya. İdarecinin Sesi Dergisi, 12-15.

Özdağ, Ü. (2015). Algı Yönetimi: Propaganda, Psikolojik Savaş, Örtülü Operasyon ve Enformasyon Savaşı (3 b.). Ankara: Kripto Yayınevi.

Özer, Ö. (2012). Haberi Eleştirmek, Haberin İdeolojik Duruşu: Eğitim-Sen Eyleminin Türk Basınında Temsili. Konya: Literatürk Yayınları.

Pratt, D. (2017). Manipulation:Beginner's Guide to Learn and Develop the ArtofManipulation. USA: Createspace Independent Publishing Platform.

Rek-Wozniak, M., \& Wozniak, W. (2020). BBC's Documentory "Stadiums of Hate" and Manifacturing of The News: Case Study in Moral Panics and Media. Journal of Sport and Social Issues, 1(19), 1-24.

Toktay, Y. (2019). Sosyal medyada dezenformasyon, manipülasyon ve propaganda etkisi : zeytin dalı harekatı örneği. İstanbul : Marmara Üniversitesi.

Turan, C. (2015). Açıklığın Yanılsaması: Dezenformasyon Çağımızın Kitle İmha Silahı mı? Akademik Bilişim Konferansı (s. 110). İstanbul: İstanbul Üniversitesi Enformatik Bölümü. 
Turan, H. (2015). Davranış Bilimleri (2 b.). Ankara: Seçkin Yayıncılık.

Van Dijk, T. (2015). Critical discourse analysis. D. Tannen, D. Schiffrin, \& E. Hamilton içinde, In The Handbook Analysis (s. 465-485). Oxford: Blackwell Publishing.

Yoloğlu, N. (2017). Küresel Medya ve İletişim Anlayışında Aktüel Enformasyondan Dezenformasyona Yöneliş. Middle Black Sea Journal Of Communication Studies, 2(1), 8-15. 


\title{
The Manipulation of Perception Against Turkey by Western Digital Media: An Empirical Research on Coronavirus News
}

\author{
Mehmet Ulaş (Res. Asst.) \\ Abuzer Yeşil (Lect.)
}

\section{Extended Abstract}

According to the liberal approach, media professionals are autonomous and logical individuals who manage to understand and objectively convey social realities and have the capacity to present this news objectively. It can be said that the idea that the media is the mirror of reality is formed at this point. For the objective presentation of the news, it should be equidistant to the sides and for this, the news should be balanced. For balance, it is important not to comment on the news with personal thoughts, beliefs, and emotions. Another situation for balance is to give equal parts and time to the sides of the news and to convey their thoughts. When looking at the critical approach, the instrumentalist approach, which is one of its sub-approaches, accepts that the news was biased in the interests of the ruling classes and therefore the objective news cannot be in question.

Realizing that the media is an element of power over the social structure in the globalizing world, it is seen that capital owners make their investments towards the information field. These developments caused a change in the characteristic features of the news and the news turned into a commercial commodity that served a certain kind of reality from a social moral issue that reflected the truth. This situation reveals the fact that it targets disinformation in the context of the content offered by the news and the construction of a manipulation aimed at the target audience. The media started to build content with manipulative effect by taking the background of an important mission such as meeting the needs of the society to obtain accurate, impartial and truthful information about the developments in the world, by considering the benefits and interests of the power focus in the presented news, and to aim to increase the ratings and circulation and its mission of journalism, whose reality has become controversial, has become its mission. Due to these transformations, the extent to which the messages conveyed to individuals from media organizations, which have a voice in the orderly formation of the world of meaning in the orderly formation of individuals within the social structure, represent the reality phenomenon. With the help of various programs, manipulations and consciously produced content in the visuals and videos presented in the news content have changed the individuals' world of ideas, values and understanding of reality. These opportunities provide a chance to provide the public with critical importance, especially in terms of political purposes. With the news content, which has an important effect on directing individuals, it is ensured that various perceptions about the world of thought are constructed and a mental blur is revealed.

As a result, those who want to make a draft community together with perception management have not been insensitive to digital media and digitalized people, which are improving day by day and improving themselves. Considering the usage rates of digital media and the developing technological structure, social media applications justify this insensitivity. The perception and social engineering, which is tried to be built with the traditional media understanding, has become much faster and feasible with the opportunities offered by digital media and digital media. The lack of an effective control 
mechanism, especially in social media, is one of the factors that make these areas more open to provocation. For a specific purpose, a detailed analysis of the target audience constitutes the basis of social engineering. Preparing the right content with the right strategic moves and presenting them with the right media channels reveals the visuality of the new social structure.

It is seen that the political balances of the countries among themselves are reflected in their media, and manipulations can be made in the news contents according to the friendly enemy distinction. As a result of the findings of the research, Western countries have tense relations after Turkey has been shown as a target in the western media for a while. In the western world in the last period, when thoroughly the impact of the rising wave of nationalism and Islamophobia also added, Turkey is becoming marginalized of the more remarkable. Indeed, although some news of this mosque also used a mosque in visual perception management production of double effect is selected from Turkey (Islamophobia and anti-Turkey) reveals the effort. Noting with alternative discourse to produce power in global politics in recent years, Turkey's goal of placing the board, as well as damaging Turkey's international image as explained by providing a consolidation effort over the enemy in their perception of the public.

In this study, criterion sampling, which is a purposeful sample, was used in the context of qualitative research methods. There are three criteria set for substantially example: firstly, the image used in the first Corona virus news is from Turkey, secondly the news that this image was seen didn't mention about Turkey and thirdly, the news was served in digital arena throughout the world. In the context of these criteria, the news contents of BBC News, New York Times, CNN International, RT, The Associated Press, The Independent and The Guardian media in digital media related to Corona virus were examined. These content that might affect Turkey's image in a negative way is discussed in the context of critical discourse analysis. Thus, in this study, it is aimed to reveal the perception management effort made with manipulation and disinformation techniques in digital media.

Keywords: Digital Media, Perception, Perception Management, Manipulation, Disinformation, Covid-19. 